\title{
An Inka Offering at Yayno(North Highlands, Peru): Objects, Subjects and Gifts in the Ancient Andes
}

\author{
George F. Lau
}

\begin{abstract}
While Marcel Mauss's landmark essay on The Gift has been vital in social anthropology, inspiring a vast and influential secondary literature, the gift has been much less prominent in archaeological interpretation. This study considers evidence for an ancient Andean gift economy, a system of reciprocal exchanges focused on making people and ensuring group so-cial relations, rather than accumulating wealth/capital. Excavations at Yayno (north high-lands, Ancash, Peru) revealed two features dating to the time of the Inkas: 1) a slab-lined cist burial; and 2) an offering deposit containing abundant long-distance trade and sumptuary items. Besides its mountaintop location, the burial's intrusive character and foreign items indicate that the offerings were made to propitiate the place, ruins and their divine aspect. This essay studies the reciprocal acts that led to the offerings, comparing them to gifting patterns in Inka human sacrifices known as capac hucha. The key actors in the exchange were children, divinities, Inka bureaucrats, local leaders and state subjects.
\end{abstract}

Ever since Marcel Mauss's Essai sur le don (1967 [1925]), gift exchange has held an esteemed place in scholarship. It is one of anthropology's core themes, in large part because of its common, yet varied, rele- vance for human solutions to value, sociality and pol- itics across space and cultures. The large ethnographic literature inspired by Maussian perspectives has il- luminated how the gifting of material culture gener- ates persons and orients social relations, usually in native, non-monetized and non-capitalist economies (e.g. Gregory 1982; LéviStrauss 1969; Sahlins 1972;

Strathern 1988; Thomas 1991; Weiner 1992). ${ }^{1}$

The subtitle to Mauss's work in English, 'Exchange in archaic societies', signals the antiquity of gift giving, but archaeological treatments have been limited. This can be attributed, at least in part, to ar- chaeology's relative inability to capture what Morris (1986, 2) lamented as an 'ephemeral phenomenon, ar- chaeologically invisible', for 'most social contexts of prestation produce no archaeological residue'.

Despite its vast propensity to harbour material things, the archaeological record is partial and slow to reveal about the desires of exchange partners, hand- tohand transactions and, crucially, the extended pro- cess of gift giving. These, and how they are imbri- cated in broader institutions, practices and meanings (Mauss's system of 'total prestation'), may be evi- denced more readily through ethnography or history. By the same token, gift exchange has featured pro- ductively in the archaeology of other world regions (e.g. Clark 1965; Fowler 2004, ch. 3; Morris 1986). That comparable studies on the ancient Americas, es- pecially the Andes, have been relatively rare is no- table since theorization of 'gift economies' often relies on Amerindian practices and ethnography (Graeber 2001; Mauss 1967 [1925]; cf. Oliver 2009).

This article examines an archaeological context as a consequence of gift exchange. It treats a secondary burial made during the time of the Inka empire (fifteenthsixteenth century ad). The offering, dedi- cated to a sacred place in highland Peru (Fig. 1), was of a young child and contained rarities of foreign deriva- tion and association to different parts and concerns of the realm. The fieldwork and ethnohistoric compar- ison enable a wider consideration of Inka-period of- fering traditions, particularly the capac hucha. ${ }^{2}$ Such offerings often involved a human sacrifice, but com- prised one component of a larger gifting relationship 


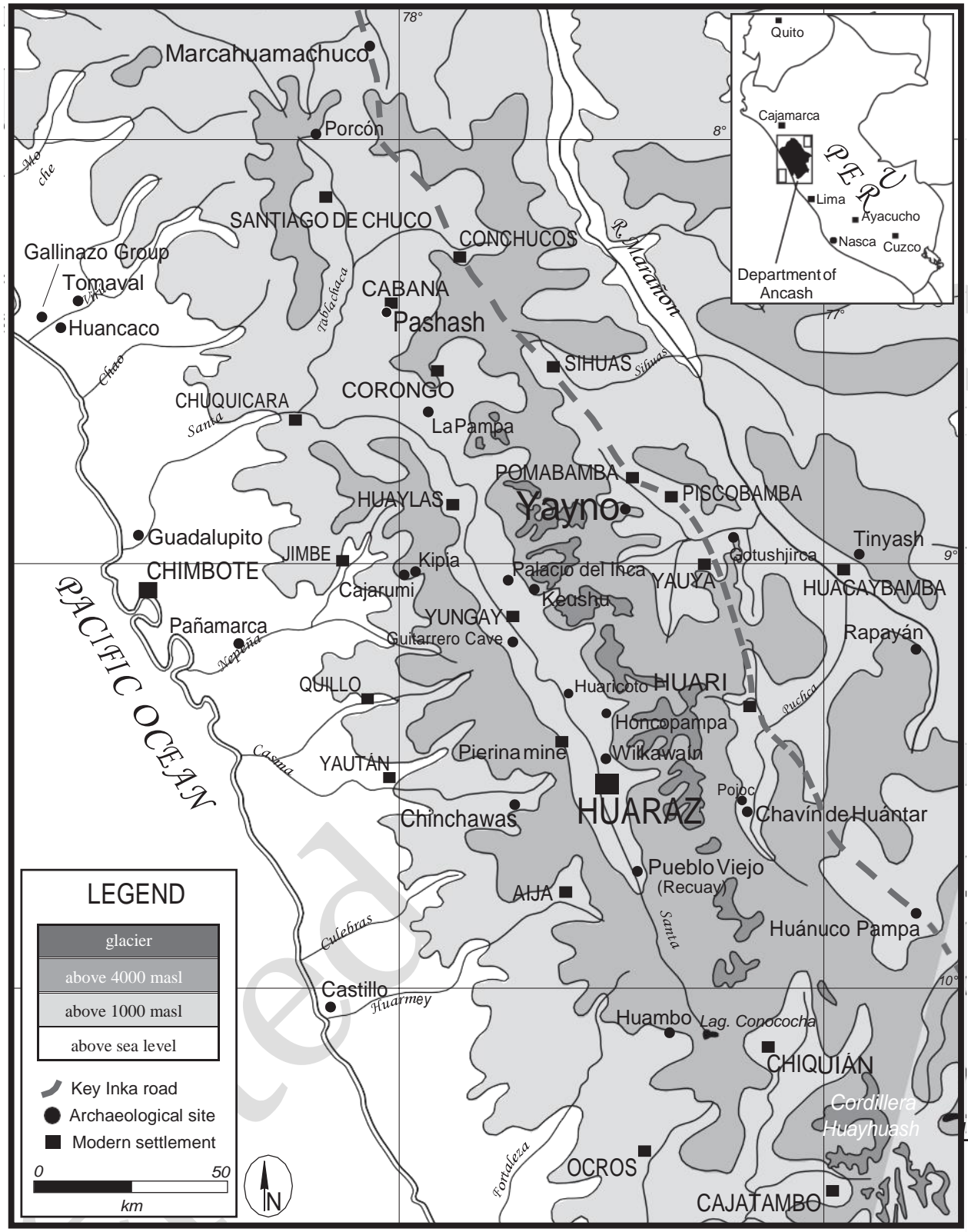

Figure 1. North-central Peru, locating Yayno and sites mentioned in text. (Map: author.)

between the empire and its provinces. The present study finds both similarities and differences to known capac hucha cases. It is argued that the Yayno offer- ing resulted from ceremonial activities that linked the Inka state to village communities and the ancient site, and engaged them in a protracted gift economy.

\section{Gifting, reciprocity and the ancient Andes}

The Central Andes is often seen as exceptional as a heartland for early civilization. State polities and com- plex arts, technologies and institutions arose without major money- or market-based exchange systems, the wheel or writing. In lieu, gifts and valuables often assumed a central role in spurring economic produc- tion. Food and maize beer, given away in feasts, en- gendered labour obligations (Hastorf 1993, 219; Mor- ris \& Thompson 1985, ch. 5). When identity, status, or subjecthood needed to be marked, cloth and at- tire sufficed (Murra 1980, 74). Small prestations and acts of hospitality served as a prelude to barter and larger-scale exchanges (Lazzari 2005, 145; Mayer 2002, 156). Portable charms ensured the health and fertil- ity of camelid herds; mummy bundles and ancestor 
effigies did the same for human groups (Lau 2013; Salomon 2004; Sillar 2012). All of these, not surprisingly, are tokens of respect and generosity that figured in reciprocal relations. In no small measure, Andean complexity was made possible by social relations of reciprocity powered by the help of embodied, mate- rial things; objects regularly mediated humans, eco- nomic production and social differentiation.

Pioneering anthropological work since Mauss has developed three of his original insights: 1) gift exchange as social contract and a system of reci- procity (LéviStrauss 1969, ch. 5; Sahlins 1972); 2) gift giving's competitive spirit and self-interest - that in giving, one acquires or keeps (e.g. debts, resources, status, fame, superiority) in relation to another (Grae- ber 2001; Weiner 1992); and 3) that gifts share in the essence and personhood of the giver, which are partible, circulated or embedded through exchange (Munn 1986; Strathern 1988; Thomas 1991). Due to preservation and limitations of the subterranean record, archaeological studies have increasingly stud- ied the third aspect, the partibility of persons - ascribing valued essences (or 'agency') of the origi- nal to objects, extensions or their fragments (Chap- man 2000; Fowler 2004; Oliver 2009). Such studies ob- serve artefactual relations that transcend the merely formal: the agency of the original can multiply and be co-present even if its parts are dispersed across space. Fragments can also be given away, but nevertheless signify or evoke the whole.

Archaeologists may infer 'gifthood' or 'personhood' from artefacts, but the identification may be synchronically restricted: the item is from a source re- gion, which is often taken, by default, as the donor's region; where it is found, meanwhile, is counted as the recipient's destination and location. The tendency towards normative flattening and palimpsest makes it difficult to reconcile Mauss's basic contention that gift exchange implies mutual obligations and a process of giving, accepting a gift, and reciprocating with a coun- tergift. Thus a cultural biography of gifts/valuables, which has been crucial in ethnographic studies, may be more difficult to reconstruct through prehistoric ar- chaeology. ${ }^{3}$

Archaeology typically addresses gift exchange as a generalized economic practice and rationalizes it as maximizing, accumulative activity and performed by actors as calculated (e.g, self-interested) strategy (e.g. Helms 1993, 92-5). Gift exchange is seen as adap- tive and more typical of kin-based societies; it pro- motes cooperation and resource sharing when kinship ties are seen to be weak or non-existent (e.g. John- son \& Earle 1987, 6-7). Scholars emphasize energet- ics: gifts and valuables are usually small and portable, and can be 'converted' into staple resources or trib- ute locally, thereby optimizing or obviating labour, storage or transport costs of bulk goods (D'Altroy \& Earle 1985). This is consistent with Gregory's (1982) influential model, which opposes commodities- ver- sus gift-based economies. The former is associated with hierarchical, class-based societies - which thrive from impersonal and market-based forms of exchange and transacted items ('commodities'). Unlike mar- ket economies, which traffic commodities to maxi- mize capital and earnings, gift economies often stress how exchanges of objects are embedded in protracted social relations, enabling certain kinds of persons and overall social reproduction. Gift economies may be privileged in smaller-scale, more egalitarian kin- based societies, where items of exchange are often highly personal, biographical and 'inalienable,' re- taining something of the giver (an individual or collective 'moral' person).

Rare precious items or materials, especially from great distances, frequently hold special value. The ability to acquire long-distance objects is often bound up with access to alterities (foreign and supernatural othernesses), which are particularly desirable to en- hance identity, prestige and/or local agency (Gold- stein 2000; Helms 1993; Nielsen 2007; Sahlins 2012). Comprehensive new volumes research the flows of resources, including of prestige items and exotics, to model more fully the array of economic practices and value systems in PreColumbian societies (Hirth \& Pillsbury 2013; Mathews \& Guderjan 2017; Pa- padopoulos \& Urton 2012). Yet there remain few case studies focused on gift exchange.

This essay examines how an Andean state sys- tem incorporated a form of gift exchange in the po- litical economy (also Morris 1986; Oliver 2009). The largest native polity of the Americas, Inka Tawantin- suyu [The four parts united], relied on a long-held value system centred on reciprocity and a multiscalar social network for redistributing key resources. The Inka state intensified festive generosity to garner a vast pool of labour for its projects - construction, war- fare, storage, herding and roads (D'Altroy 2002; Gode- lier 1977; Mayer 2002; Murra 1980). The infrastructure and activities of empire were, in no small measure, made possible through imperial gifts given in return for the allegiance and labour tribute of their subjects. The best-known prestations to provincial groups, be- sides formal recognition and privileges accorded by the Inka, were festive meals, plentiful maize beer, coca leaf and rare precious items (e.g. cloth, metal objects and marine shell) (Murra 1980; Rostworowski 1999; Rowe 1946). To this, I add the gifting of living subjects, or capac hucha. 
Capachucharitual cycle

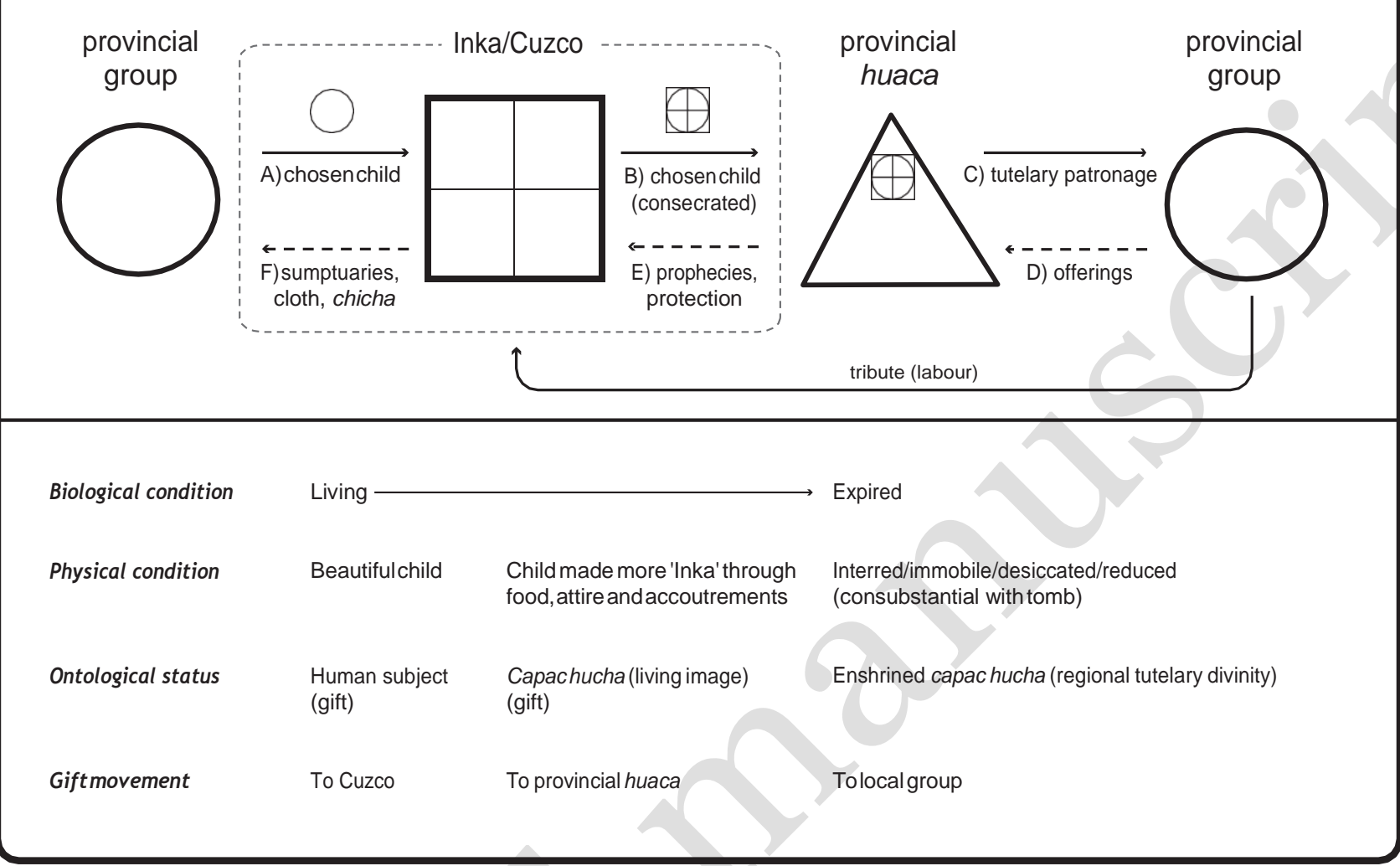

Figure 2. Capac hucha ritual cycle, showing flows of gift objects, subjects and reciprocations (denoted by arrows). Capac hucha was a practice inserted (dashed field, top register) between provincial groups and their huaca divinities. The lower register schematizes the physical transformations of the child and her/his ontological trajectory as a gift and subject. (Diagram: author.)

\section{Andean prestations}

An important native category for assessing and comparing the evidence in this study is capacocha (or $c a-p a c$ cocha) or capac hucha (or qhapaq ucha). The Quechua word has been used to describe both the act of sacri- fice and the individual sacrificed, usually a child. The term also described the entire ritual cycle (Fig. 2), in- cluding presentations, processions, feasts and gift giv- ing, a phase of which culminated in the child's immo- lation (Besom 2009; 2013; de Bock 2010; Duviols 1976; MacCormack 2000; McEwan \& van de Guchte 1992; Reinhard \& Ceruti 2010).

Capac is a Quechua honorific ['supreme', 'royal,' 'grand'] and title given to lords and things de- serving utmost regard. There is greater uncertainty about the term's second part. 'Cocha' usually refers to a lake, sea or body of water (Zuidema 1973, 28). 'Hucha', meanwhile, may mean 'peccado' [sin], 'negocio' [business/trade] or 'pleyto' [plea/dispute/contract]
(González Holguin 1989, 199; Zuidema 1982, 425-6). While 'cocha' refers to more of a tangible (watery) thing, the semantic field of ' $h u c h a$ ' connotes more about social relations, transactions and negotiated ac- tivities between people. Scholars thus take capac hucha to mean 'royal obligation' (MacCormack 1991, 104; McEwan \& van de Guchte 1992, 359), 'business' of the Inka (MacCormack 2000, 111, 122), or 'opulent presta- tion' (Salomon \& Urioste 1991, 112). Both 'cocha' and 'hucha' may have pertinence to the offering in ques- tion, but capac hucha may have special relation to its gifted, mediating or exchange quality (see also Bor- toluzzi \& Martínez Armijo 2011; Duviols 1976).

Described in various early Spanish accounts (Be- som 2009, ch. 2), capac hucha featured in the annual ceremonial cycle of Inka sacrifices and prestations, made to shrines in Cuzco, the Inka heartland (Bauer 1998; Farrington 2013) and conquered regions. The rites also marked critical royal events (e.g. succession, war, death) and times of great tumult, such as drought 
and natural disasters. The annual celebration lavished gifts to the regional gods and their priests, who visited the capital to prophesy the future for the Inka (Besom 2009; MacCormack 2000, 121).

Pedro Cieza de León, a Spanish soldier- chronicler, called capac hucha the 'gifts and offerings' made by the Inkas 'to their idols' (1985 [c. 1553], 87). The foremost prestations were beautiful children, most aged 4 to 12 years, unblemished and virgin, often born to provincial noble families. ${ }^{4}$ They were first sent to Cuzco for consecration by priests, trans- forming them, through food and finery, into suitable representatives of the Inka and its solar cult. A girl and a boy could be coupled to form a sacrificial pair, and provisioned with small dedicatory items symbolic of the house, marriage, work and livelihood (McEwan \& van de Guchte 1992, 361). Some were then sacrificed in Cuzco. Others were returned to the provinces, occasionally back to their homeland, in group processions with great pomp (MacCormack 2000, 122). They were then dispatched or buried alive in specially prepared tomb-platforms (Reinhard \& Ceruti 2010, 96-7).

The various nations that made up Tawantinsuyu each worshipped their own pantheon of divinities (huacas or w'akas) (Bray 2015; Duviols 1967); capac hucha were Inka-sanctioned gifts to these huacas. Their final destination was usually at a location of the huaca divinity, embodied as an effigy and/or landscape fea- ture. These were often visually impressive locales and greatly esteemed in social memory and local oral his- tories. Capac hucha themselves became huaca beings and their burial locations served as shrines for sub- sequent cult activities (e.g. offerings, libations, orac- ular consultations). They could be worshipped at the spot, or from a distance (Duviols 1976, 38). Provincial groups continued to venerate huacas well into colonial times, making offerings to their tutelary gods in re- turn for their protection, vitality and care; their effigies and shrines were the main targets of Christian anti- idolatry campaigns (e.g. Arriaga 1999; Duviols 1967). The processions also engaged the many ethnic groups of the lands traversed en route to the final destination. They obliged hospitality, such as gift- ing, feasting and provision of shelter (MacCormack 2000).

The ritual complex helped activate the net- works of reciprocity that comprised Tawantinsuyu, while marking group boundaries and legitimating the state infrastructure abroad (personnel, roads, installa- tions). The capac hucha cycle thus mobilized and re- distributed resources from the entire state network. It also allowed various subjects of Tawantinsuyu, hu- man and non-human, to witness and proceedings.
By creating gift relations with local divinities, the Inka benefitted because huacas were almost invari- ably linked to surrounding lands and the water and labour resources which made them productive. The capac hucha ceremonies also recognized territories, set- tled land disputes and legitimated provincial lord- ships (MacCormack 2000; Zuidema 1973). These were domains for state action that were understood as reci- procity:

... no shrine or deity, whether large or small, was forgotten in this empire wide transaction in which the Inca and his subjects gave human victims and other oblations to the deities and guacas, who in re- turn gave to the Inca their benevolence and protec- tion, as well as their hopefully truthful and helpful prophecies ... (MacCormack 2000, 124)

The 'business of the Inka,' of course, was also to de- clare that the Inka king and the 'cosmic polity' which backed him wielded the power to refashion ances- tral bodies/persons and landscapes (for 'cosmic', see Sahlins 2012). ${ }^{5}$ This was not simply ideology masking the practices of exploitation. Capac hucha had great im- pact because they reinvented provincial histories in a shared idiom of cosmopolitical relations, in which Inka authority, embodied in a living gift-in-process (laden with a future potency), could be inserted as a new, privileged power in regional hierarchies (Fig. 2). Capac hucha thus facilitated Inka intervention into already hierarchically organized, sacred landscapes (Dean 2010; Kosiba 2015; McEwan \& van de Guchte 1992; Meddens et al. 2014).

Spanish writers observed a wide range of loca- tions and activities associated with capac hucha, par- ticularly as related to the provincial huacas (see Be- som 2009). The higher-ranking huacas saw grander at- tention (Bray 2015; Duviols 1967). Archaeology has been important in detailing this variability in capac hucha practice (e.g. locations, contents, taphonomy). A few capac hucha are associated with islands and major archaeological sites, such as Túcume (Lambayeque), Pachacamac (Lima) and Choquepukio (Cuzco) (An- drushko et al. 2011; Besom 2009; Bray 2009, 360-61;

Dorsey 1901; Narváez 1995; Reinhard \& Ceruti 2010). Summit locations and ancient ruins are particularly germane to this study.

The best known cases have been found south of Cuzco, mainly on high peaks above 5000 masl. Be- cause of their remoteness and condition, these are often taken as exemplary (Farrington 2013, 314). In addition to favouring their preservation, the diffi- culty of access almost certainly limited handling and revisitation after their establishment, not least by Spaniards. Technical studies of human remains (An- drushko et al. 2011; Reinhard \& Ceruti 2010; Wilson 
Table 1. Summary of capac hucha prestations made to Tawantinsuyu by ayllu groups in southern Ancash.

\begin{tabular}{|c|c|c|c|}
\hline Ayllu & Number & Dedicated to & $\begin{array}{c}\text { Place/region of sacrifice } \& \\
\text { dedication }\end{array}$ \\
\hline Hecos & 2 & Rayo (Lightning God) & Hecos (local) \\
\hline \multirow{4}{*}{ Chaupis } & \multirow{4}{*}{7} & \multirow{4}{*}{-} & Lake Titicaca (3) \\
\hline & & & Lampas/Recuay juncture (1) \\
\hline & & & Quito (2) \\
\hline & & & Cuzco (1) \\
\hline Hichoc & 4 & Inca (king) and sun & Cuzco (4) \\
\hline Caquimarca & 5 & - & $\begin{array}{l}\text { Quito, Cuzco \& Huánuco Viejo } \\
\text { (numbers unspecified) }\end{array}$ \\
\hline Olleros & 2 & $\begin{array}{l}\text { Underworld gods (Huari), } \\
\text { subterranean pits with clay }\end{array}$ & Olleros (local) \\
\hline \multirow{5}{*}{ Chaupis Churi } & \multirow{5}{*}{12} & \multirow[t]{5}{*}{ 'huaca de Quito' } & Quito (4) \\
\hline & & & Cuzco (3) \\
\hline & & & Lake Yahuarcocha (2) \\
\hline & & & Chile (1) \\
\hline & & & Lake Titicaca (2) \\
\hline
\end{tabular}

et al. 2013) and pottery (Bray et al. 2005) confirm that both humans and artefacts in capac hucha interments originated from different parts of the realm, includ- ing local and foreign (including Cuzco) elements. In general, there is much less evidence, documentary or archaeological, about capac hucha locations, after enshrinement.

Additional insights can be found in colonial inquisitional documents, which recorded native testimonies of the Christian campaigns against pagan religions, or 'idolatries'. A 1621-22 account of south- ern Ancash observed that most kin groupings, called ayllu, ${ }^{6}$ admitted capac hucha in their cult practices (Hernández Príncipe 1923). Key details can be gleaned for these groups, who were close cultural and geo- graphic neighbours of Yayno's peoples (Table 1). First, while some ayllu might have (or reported) no capac hucha, other ayllu registered more than one, and up to 12 - a substantial total for a small area of southern Ancash. Second, the human sacrifices were sent to sig- nificant places throughout the empire. Third, the sac- rifices were made for regional divinities, sacred places and 'amistad' [friendship, good relations] between ri- val factions. The ritual also allowed the Inka to re- ward loyal subjects (Zuidema 1973; 2015). Finally, the ayllu groups still very much identified with their capac hucha, and regarded them among their most important cult places and patrimony, nearly a century after the dismantling of the Inka system.

While capac hucha has been studied primarily as state ceremony and human sacrifice, the ethnohisto- rian Pierre Duviols $(1976,29)$ noted its essential redis- tributive quality and likened it to a 'circulatory sys- tem' with Cuzco as its 'heart'. He theorized a series of reciprocal movements and gifts. Some were cen- tripetal, manifested by tribute and resources, includ- ing the chosen children, entering Cuzco. Others were centrifugal, when the capac hucha is sent back out to the provinces with return gifts for their local huacas (also Dean 2010, 101). Duviols observed, 'The Inca

... is implicated in a contract (minka) of the capacocha in which he is recipient, debtor and intermediary, at the same time, and within the relation, so created, of producer and consumer'; just as important, capac hucha intervened in local politics, having 'the func- tion of settling accounts by means of a complex sys- tem of gifts and countergifts' (Duviols 1976, 31,34, my translation). ${ }^{7}$

In short, capac hucha formed an integrated so- cial phenomenon, in the Maussian sense. More than a routine transaction between individuals (of alien- able objects in regular, forgotten events), the gifting cycle of capac hucha comprised an enduring field of so- cial relations between entire groups which involved 'institutions [that] find simultaneous expression: re- ligious, legal, moral and economic. In addition, the phenomena have their aesthetic aspect ... the source of aesthetic emotion and emotions aroused by inter- est' (Mauss 1967 [1925], 1, 77). Scholarship has cer- tainly noted the socio-political implications of capac hucha and how it helped integrate different parts of Tawantinsuyu (Besom 2013; Duviols 1976; MacCor- mack 2000, 120; McEwan \& van de Guchte 1992; Rein- hard \& Ceruti 2010; Schroedl 2008). It remains to detail the prestation in this 'total prestation' system, partic- ularly its archaeological expressions and variability. 


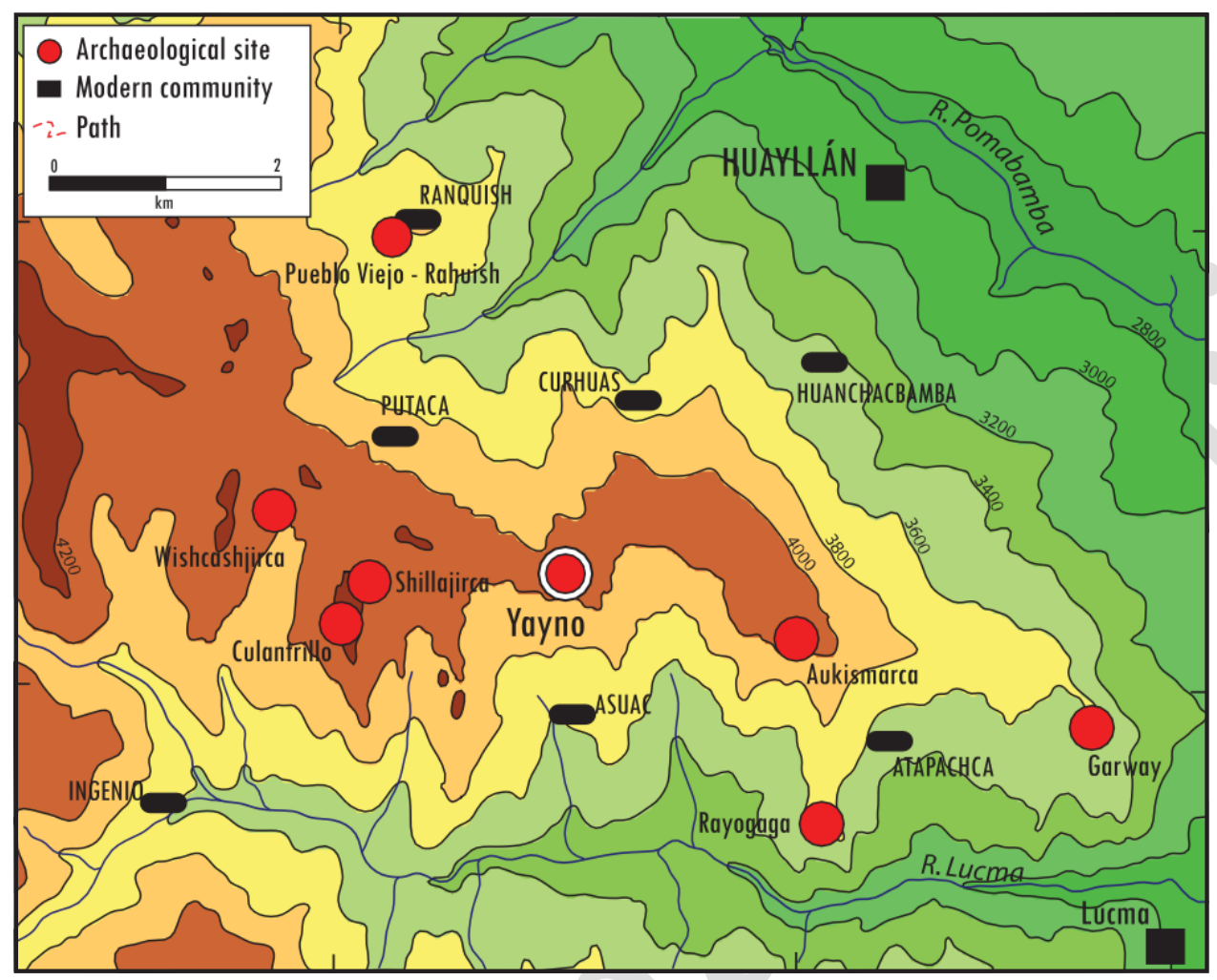

Figure 3. (Colour online) Location of Yayno and surrounding sites and villages with late period (Inka-contemporary) components (Rahuish, Culantrillo, Wishcashjirca, Shillajirca, Rayogaga and Aukismarca). (Map: author.)

\section{Yayno and the offering context}

Today, Yayno is the most prominent archaeological site in the region (Pomabamba, Ancash), covering approximately 105 ha of a low mountaintop, Cerro Pañajirca, and adjacent areas (Fig. 3). The site was origi- nally a large fortified village and one of the major cen- tres of Recuay culture, dated to approximately cal. ad 400-800 (Lau 2010; 2011).

In addition to its strategic location overlooking the confluence of two rivers, Yayno was probably appreciated for a number of prominent visual characteristics, visible from kilometres away. It has a distinc- tive mound-platform profile (Fig. 4). It is also partly ringed by large erosional channels. Some sections functioned as defences and are walled on the upslope side. Another major feature is a rock formation on the northwest summit face, split into five columns or shal- low fins jutting out from the outcrop (for the signifi- cance of 'five' in Andean thought, see Donnan 2009, 177; Salomon \& Urioste 1991, 270; Urton 1997, 215). ${ }^{8}$ Yayno's western side also affords unobstructed views of the Cordillera Blanca (Apolín G. 2009). The inter- visibility between the Yayno's crest and surround- ing peaks may have been meaningful in the past, since many oral traditions regard mountains, espe- cially glaciers, as local 'lithified' ancestors, with the capacity to see, witness and act (Lau 2016; Venturoli 2011; Yauri Montero 2000).

Yayno's main sector was densely built up with over 50 walled compounds used primarily as the house complexes for kin groups or lineages of variable size (Lau 2010). The compounds have both round and quadrangular layouts; the largest towered over $12 \mathrm{~m}$ tall and had multiple storeys of apartment-like rooms which opened into an unroofed, interior courtyard space. The most monumental compounds have large courtyards, elaborate drainage and visually striking stonework façades. At its height, Yayno was home to approximately 600-900 people (Lau 2010, 342), but was largely abandoned by the ninth century ad.

Post-Recuay floors and ceramics, in general, are rare. Any later additions are almost all simple, expe- dient constructions, probably makeshift shelters and corrals, which robbed stones, incorporated parts of old walls, and rarely employed mortar. More per- manent post-Recuay village and hamlet sites occur within a few hours' walking distance (Fig. 3). Unlike Yayno's discrete compounds, these later villages ag-glutinated dwellings along the concentric walls that 


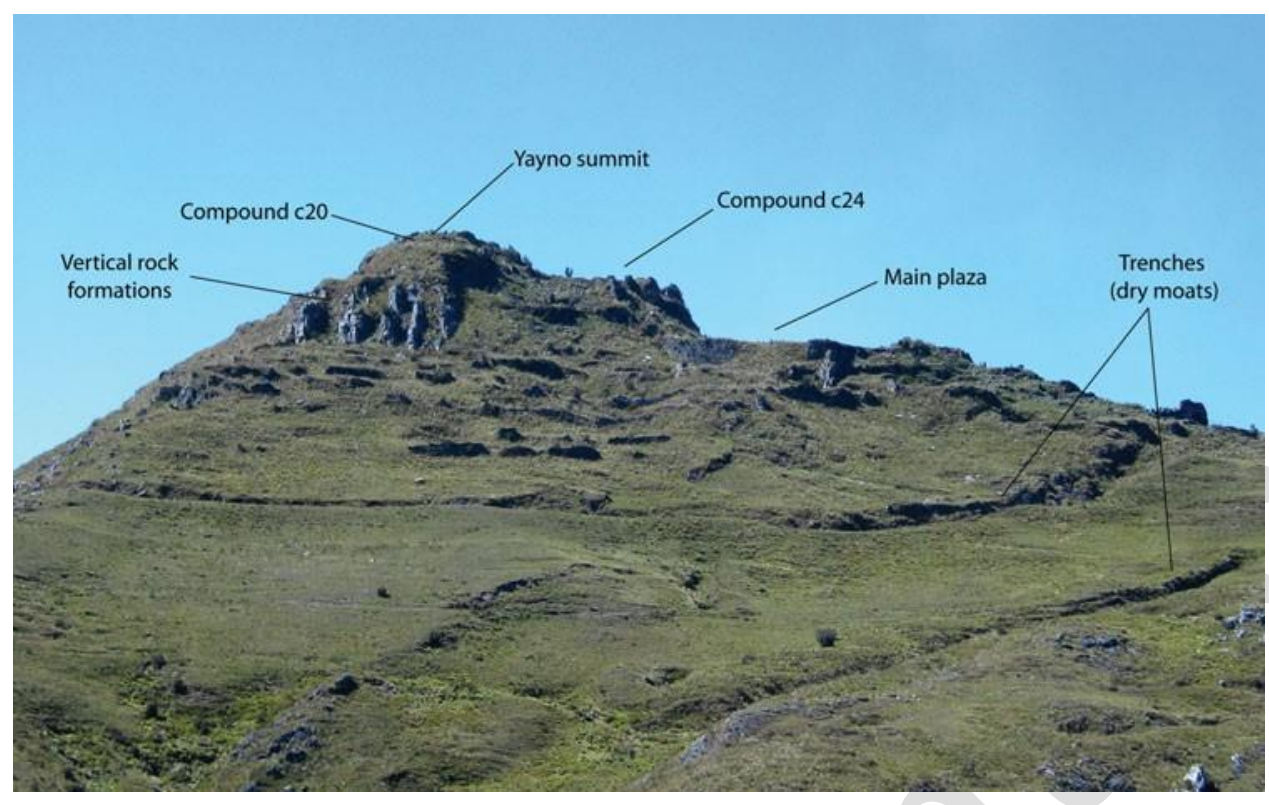

Figure 4. (Colour online) Northern face of Yayno. Yayno's visual properties (rock formations, terraced profile, vistas, monumental ruins) were important in the past, and continue to distinguish the mountain and its imagination today. (Photograph: author.)

encircled the entire settlement. Late-style pottery and grinding stones are common at these villages and many hilltops in the region, but not at Yayno. With Yayno in ruins, most local groups, by Inka times, ap- pear to have resided in lower-lying villages flanking its mountaintop. ${ }^{9}$

The offering context was found in the courtyard of c20 (circular compound originally of Recuay date), a walled and partly sheltered spot just below the sum- mit (4150 masl) (Fig. 5). The compound sits directly atop the columnar formation previously mentioned; the outcrop is the building's foundation. Locating the burial in c20 protected it from erosion and allowed pe- riodic offerings to pool in the patio.

Excavations in c20 included a test pit and a larger exposure, Operation 16 (c. $48 \mathrm{~m}$ ). Immedi- ate signs of unusual deposits were small beads (made out of turquoiseand green-coloured stone), Spondy-lus sp. shell, obsidian flakes and gold metal foil fragments (láminas). None of this material has been found elsewhere at Yayno, nor is common at other Recuay-period sites. As the excavation progressed, the rare items became more frequent. These were sometimes accompanied by well-preserved, occasionally articulated bones of young camelids. Many complete Spondylus valves also appeared. Two small clus- ters of whole valves were found atop a hardened earth stratum about $5 \mathrm{~cm}$ above bedrock (Fig. 5). The shells were positioned as if originally stacked, and had fallen over. The uneven bedrock resulted in an elevated area (towards the summit), and poorly preserved portions of a beaten dirt floor above it probably served as the main original surface for the offerings. Towards the centre-north, a low hollow was exploited to make a cist. Three flat stone (schist?) slabs, roughly quadrangular in shape, were propped up to form the cist's walls; bedrock formed the remaining side. No mortar was used. The cist, c. $35 \mathrm{~cm}$ wide $30 \mathrm{~cm}$ deep, was covered over by a fourth slab.

On the cover slab were two shattered, but largely complete Inka-style ceramic vessels (Figs. 5 \& 6). ${ }^{10}$ One was a small olla, a wide-mouthed jar (mouth diameter 12 $\mathrm{cm}$; height $c .22 \mathrm{~cm}$ ), featuring an un- slipped light-orange paste, arching strap handle and tall pedestal base (Morris \& Thompson 1985, pl. 7; Reinhard \& Ceruti 2010, fig. 7.23). The other was an- other distinctive Inka form ('urpu'), with a tall flar- ing neck, conical globular body and tapering base (mouth diameter $9 \mathrm{~cm}$; height $c .33 \mathrm{~cm}$ ). The front body and neck were slipped dark purplish red; the front was painted in dark geometric motifs, mainly rows of triangles within thin bands. The smoothed back side was unslipped and unpainted, but show- ing light brownish paste and fire clouding. It had two side strap handles, and two perforated nubbins underneath the flaring lip-probably to secure a lid. The front shoulder has a projecting lug, incised with a ' $U$ ' form. The urpu's front side was intentionally smashed, perhaps to terminate the vessel and burial ritually. ${ }^{11}$ 


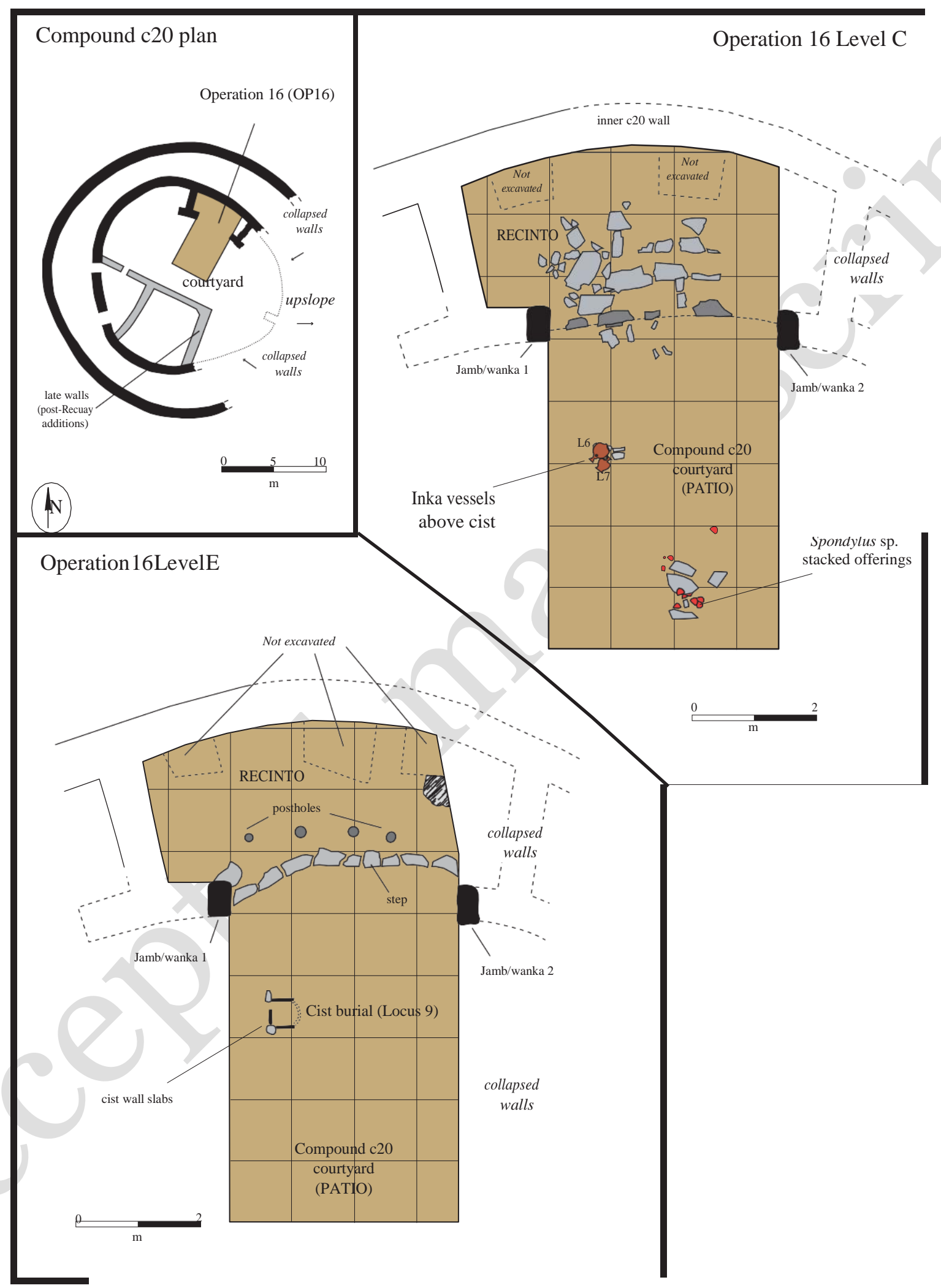

Figure 5. (Colour online) Layout of Compound c20 and plans of Operation 16 excavations. The burial cist and offerings resulted from Inka-period activities within a circular construction buit by Recuay groups roughly a thousand years earlier. (Author.) 

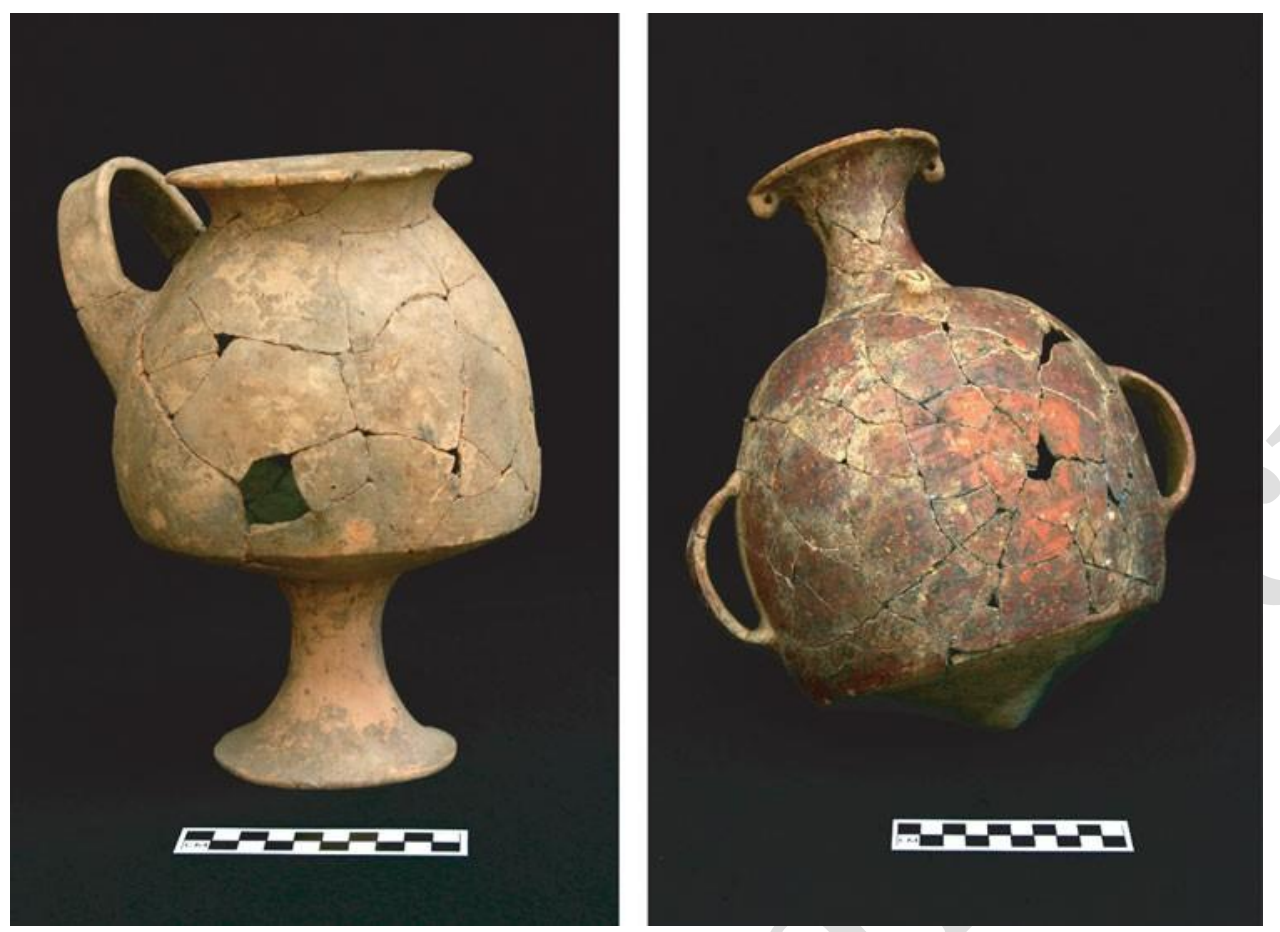

Figure 6. (Colour online) Inka style ceramic vessels, Operation 16. (Photographs: author.)

The cist contained heavily eroded fragments of dark brown wood (Fig. 7b). Several featured a con- cave body and rim, almost certainly of an Inka-style tapered drinking cup, or kero. One fragment shows incision directly below the rim, in triangular pen- dants filled in with lattices (pointing downwards), al- ternating with upward-pointing triangular pendants filled in with horizontal hatching. Several body frag- ments show a chevron design, oriented vertically. The designs are very similar to those on wooden keros found at capac hucha sites (e.g. Reinhard \& Ceruti2010, fig. 7.30).

Cloth fragments probably belonged to a mantle or tunic (Fig. 7d). All fragments used a plain-weave technique, featuring camelid warp and weft fibres (Z-spun and S-plied: $S(2 z)$ ). Despite staining, dark brown, greyishbrown and black colours could be dis- cerned. This kind of cloth is typical of highland An- cash groups of the Late Intermediate Period and Late Horizon (c. ad 1000-1532) (Brito n.d.).

The cist also contained a matching pair of cop- per and silver metal tири (pins to adorn and fasten garments). Each has a very large ovoidal disc head of hammered sheet (Fig. 7c), and a hole perforating the disc right above the shaft. Тири 1 is best preserved $(22.9 \mathrm{~cm}$ long, disc width $11.2 \mathrm{~cm}, 42 \mathrm{~g}$ ). Its disc head has small cloth pieces clinging to it, stuck together with the green corrosion of copper metal. Tири 2 (35

$\mathrm{g}$ ) is more fragmented, but features original thread, thickened at the preserved end, running through its hole (Fig. 7c, inset). A cloth fragment with original edge shows a hole, encrusted, through which one of the pin shafts was pushed. The cist also contained a thin gold-metal lámina fragment.

The only human skeletal material was a partial cranium (Fig. 7a), found above the artefacts; mandible and teeth remains were nearby. Age at death was es- timated at 4 years ( 12 months; tex indeterminate) (Pomeroy n.d.). Tири pins were vital markers of Inka female identity (Vetter \& Carcedo 2009) and it is sug- gested, tentatively, that the skull was of a very young girl. Mostly the skull's anterior portion survived, with little evidence of pathology. Much of the bone surface was covered in a dark brown deposit, probably pre- served soft tissue. The teeth, maxilla and isolated ar- eas of the face were stained green due to contact with a copper-containing metal, probably the tupus. Another copper-bearing object may have been placed in the mouth, given the extent of green staining on the pala- tine process and teeth.

The offering area around the cist, meanwhile, contained impressive quantities of rare precious items. The Spondylus sp. shell represents the largest assemblage known from the sierra of Ancash, if not all of the Peruvian highlands outside of Cuzco. The 861 specimens weighed $10.6 \mathrm{~kg}$, including 79 mostly whole valves and at least 86 other valves (MNI). Most whole specimens measured 8$10 \mathrm{~cm}$ (max. 

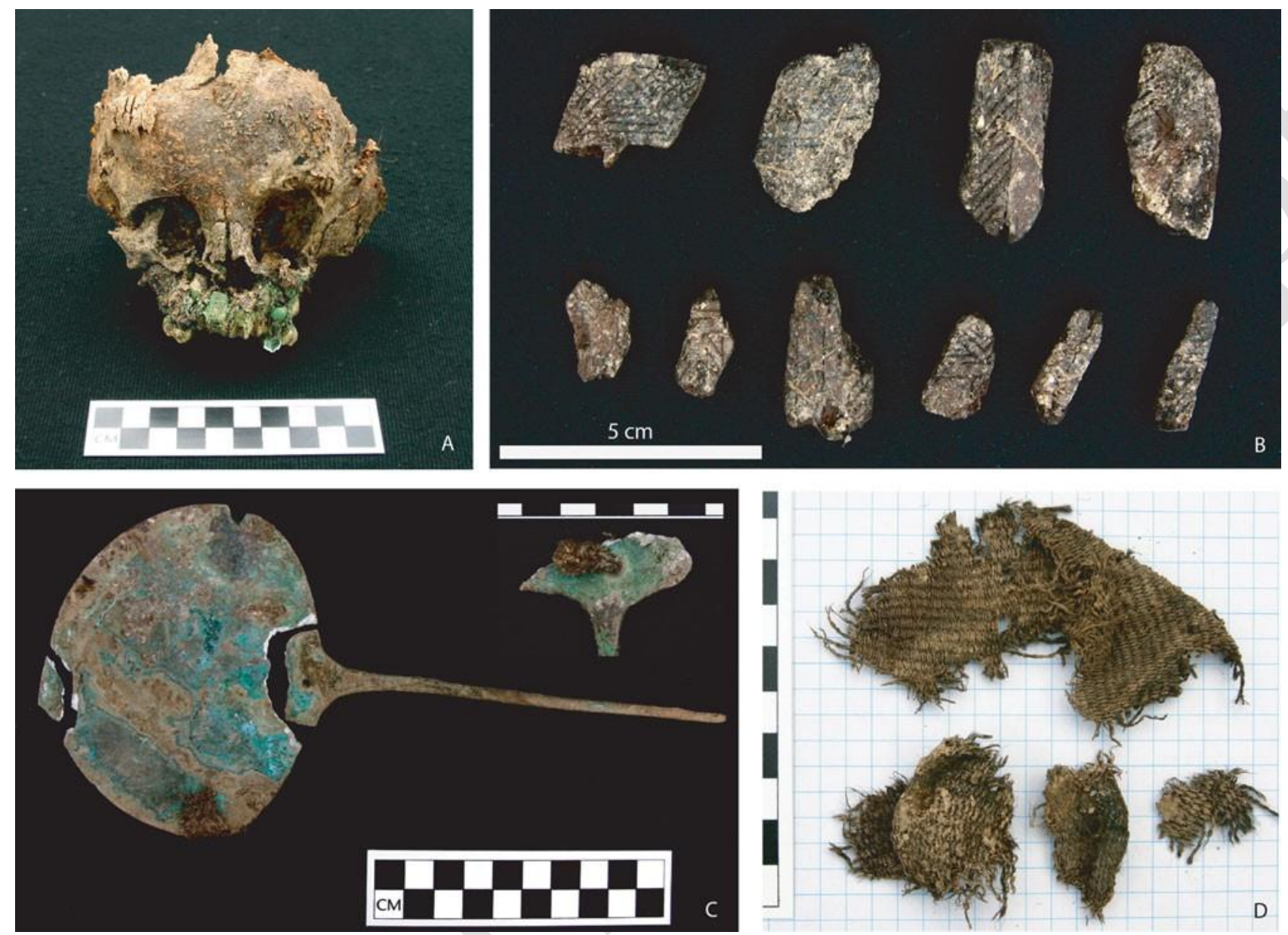

Figure 7. (Colour online) Contents of cist: (A) incomplete child cranium; (B) fragments of wooden kero, some with incised geometric designs; $(C)$ tupu pins, showing fragments of cloth; $(D)$ fragments of woven cloth. (Scales in cm.) (Photographs: author.)

dimension) and were largely unworked (Fig. 8), although some had been partially ground down, drilled, or had their spikes removed. On many, the shell colours (red, orange, pink (with white)) have faded, probably due to sun and rain exposure and/or deposition in seasonally wet soil. A trapezoidal shell pendant was also recovered in the find layer. ${ }^{12}$

Excavation and fine sieving recovered over 1208 beads (Fig. 9). Most were of green- and turquoisecoloured stone. A few used other materials: stone (red, light brown, dark grey), corroded copper, clear glassy blue stone (quartz?), and maybe shell. Bead size varied greatly, most between 2 and $5 \mathrm{~mm}$; several reached $2 \mathrm{~cm}$. There is no outward standardization in their shape, suggesting they are not mainly from one object (e.g. necklace) or production source. Excava- tions also encountered some broken beads, pendants, chunks of raw material and four unworked quartz crystals. ${ }^{13}$
In addition, the deposit contained 142 small hammered sheet artefacts (láminas), almost all goldcoloured metal (Fig. 10); seven were silver metal. These were small and very thin and mainly quad- rangular or circular in shape. Many were irregular, folded over, creased, or broken/cut purposefully as fragments. Many were perforated, with one (n 41) or two holes (n 19); occasionally, the position and rough edges of the holes suggest expedient perforations af- ter original production and use. Several showed sur- faces with red pigment. A thick lámina $(0.95 \mathrm{~mm})$ (Fig. 10) and a solid gold ball resembling small bird- shot (d. $5.18 \mathrm{~mm})$ may have been blanks for additional hammering. There were also four hammered sheet- metal beads: one with corroded copper surface, an- other of gold metal and two of silver metal.

Ten radiocarbon assays date Yayno's Recuay occupation to approximately cal. ad 400-800 (Lau 2010); no samples have yet been tested for the Inka 


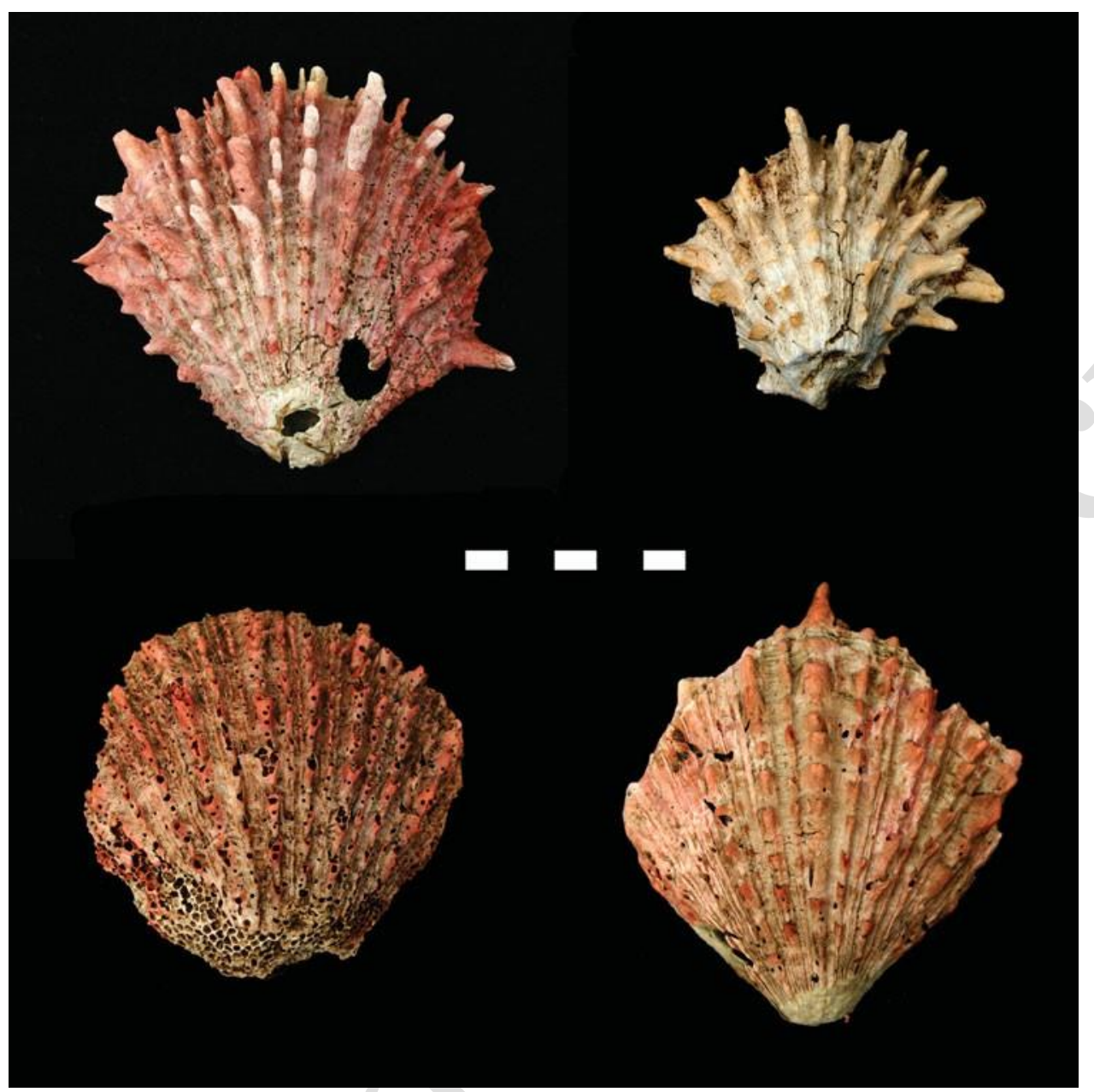

Figure 8. (Colour online) Spondylus sp. shell valves, offering deposit in Operation 16. (Scale in cm.) (Photographs: author.)

burial/offering. These notwithstanding, historical accounts indicate the region's annexation some time af- ter 1460 , when many northern territories were added to the empire, and before its demise in 1532 (Rowe 1946).

\section{Discussion: ruins, precious items and gifting}

The excavation thus revealed two principal features of post-Recuay date: 1) a slab-lined cist containing a child skull and Inka-style artefacts; and 2) an adjacent deposit containing dispersed remains of various small precious items. The burial's intrusive character, place- ment and long-distance items suggest that the cist and offering were made during Inka times to propitiate the Yayno mountaintop, its ruins and divine aspect, or huaca.

The Yayno case demonstrates similarities to $c a-p a c$ hucha practices, but also some notable distinctions. First, most archaeological and textual cases of capac hucha describe Inka child sacrifices as complete individuals and positioned where they were dispatched (Andrushko et al. 2011; Reinhard \& Ceruti 2010; Wilson et al. 2007; 2013). Ethnohistorical accounts em- phasized the body's integrity and condition: selection of unblemished individuals, their involved bodily preparation and manner of immolation; such prac- tices made the offering suitable

for the gods (MacCor- mack 2000, 130-31; Reinhard \& Ceruti 2010, 125-6). ${ }^{14}$ Although the skull had been removed earlier, not much can be inferred about the intervening time between death and cist placement. Perhaps only the head was significant or retrievable at the moment of acquisition/burial. Only a portion of the courtyard was tested due to time constraints; wider excavation may expose a fuller picture of the offering context (e.g. additional cists, human remains). The child's es- timated age at death, 4 years ( 12 mohths), is at the lower prescribed range for selection (Besom 2009, 28;

12 MacCormack 2000, 120); it is not known if the young 

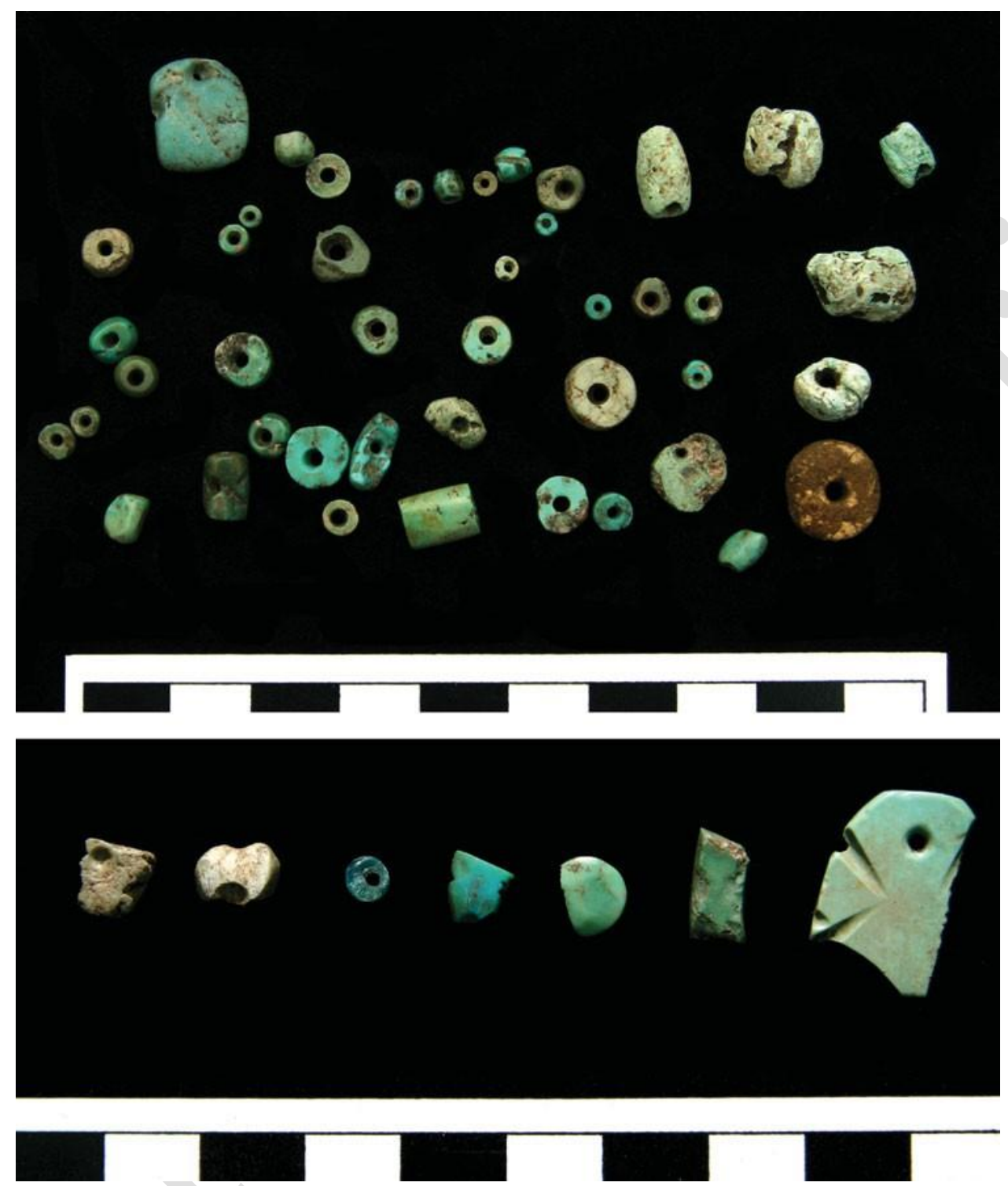

Figure 9. (Colour online) Beads and lapidary material in offering deposit. Although green-and turquoise-coloured stone was the most popular material, excavations also encountered beads of red and beige stone, glassy light-blue crystal and metal (copper, silver and gold). Broken and incomplete pieces and raw chunks of semi-precious stone material were also included in the offering deposit. (Scales in cm.) (Photographs: author.)

age may have affected the child's handling or disposition (Wilson et al. 2013, 13323). There are no clear signs of how the child died, so whether the death was 'gentle .... quiet and peaceful' cannot be determined (MacCormack 2000, 132). Bodiless heads have been found with Inka offerings in other imperial provinces (Narváez 1995, 113). ${ }^{15}$

Ritual practices to bury children and infants have varied over the long cultural history of the Andes (e.g. Arriaga 1999; Dillehay 1995; Farrington 2013; Klaus \& Toyne 2016). Some practices favoured their rapid disposal, evidently to forget and distance the corpse soon after death. Other traditions sought to memo- rialize or lavish attention on their remains, despite the young age and potential uncertainty about status (Baitzel \& Goldstein 2014; DeMarrais 2013). Like capac hucha more generally, the Yayno burial did not aim to forget the child individual, as much as it sought ac- tively to construct a new identity and celebrate Inka- sanctioned associations.

Because the activities that led to the Yayno con- text occurred over time, comparison to capac hucha, the best known programme of Inka provincial offering rit- ual, may help to schematize different stages (Fig. 2) 

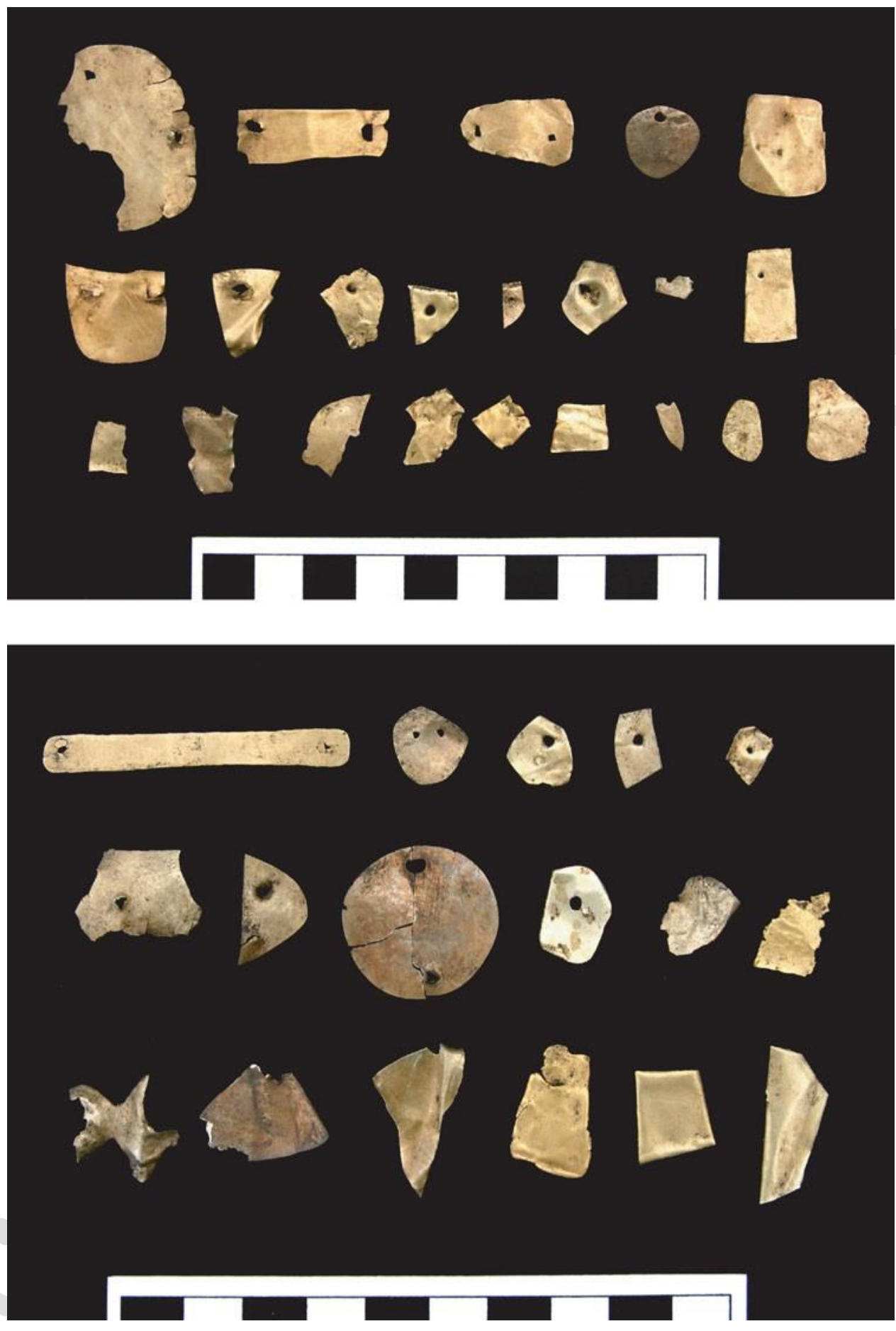

Figure 10. (Colour online) Gold-metal hammered sheet láminas. Note the variability in form, as well as condition. Many are irregularly shaped, cut and perforated expediently, or broken. Top image shows a thicker gold piece, perhaps a small blankfor additional hammering (bottom row, second from right). (Scale in cm.)(Photographs: author.)

and patterns of its deposition. The extended ritual sequence involved young children who undergo transformations in corporeal form while occupying different subject-object statuses. The initial step (Step
A) centres on a human subject, a beautiful child, who is gifted with other objects to the Inka and sent to Cuzco for preparation into a living sacrificial im- age. This involved a new diet with varied high-status 
comestibles, including maize, maize beer, coca, meat and other privileged foods (Bray 2003; Wilson et al. 2007; 2013). Once refashioned, s/he then becomes a suitable prestation (object) for the pantheon of deities in Cuzco and the provinces (Step B). The return jour- ney involved ritual processions, feasting and consum- ing the blood of sacrificed Inka-bred camelids, a form of communion with the Inka (MacCormack 2000, 113, 138). Known child sacrifices also show ingestion of coca and alcohol, both psychoactive substances, dur- ing the lead-up to their immolation, perhaps to help their long journey or sedate before killing (Wilson et al. 2013). Lastly, enshrinementof the capac hucha's ex- pired body in a tombprecipitated the gift's own di- vine subjectivity, whose enduring purpose was to give back (Step C) to the provincial communities who re- ceived, and venerated, her/him as their own.

Crucially, the oscillation of subject-object sta- tuses follows the different phases, or routing, of the child as a gift. In the transition to becoming divine, the exchanges are synchronized to highly managed alter- ations of a child's body-from selection and enhance- ment (through diet, clothing and travel) to its contain- ment and expiration, and ultimately to desiccation, decay and reduction. One hypothesis for the Yayno burial, containing only the cranium, would be that it resulted from an extra bodily change (and movement) occasioned in the extended cycle (Fig. 2). The skull's lone presence is made more marked, even paradox- ical, given that the artefacts (kero, pins, cloth, pots) were all intended, notionally, to enhance the trunk portion of an individual's body.

The other notable contrast concerns the forms and disposition of the Yayno offerings. Most archae- ological cases of capac hucha feature the grave items within arm's reach of the sacrificed bodies and within the burial space (Reinhard \& Ceruti 2010). At Yayno, the burial compartment is relatively small and con- tained few items; the Inka pots were on top of the cist. ${ }^{16}$ Abundant precious items, especially beads, gold láminas and Spondylus shell were left above and around the cist. The bones of young camelids (proba- bly food offerings), obsidian and quartz crystals were also found with the other rare materials.

Stratigraphy and artefact patterning indicate that these remains accumulated after the cist interment, probably left intermittently over a period of time, as countergifts to the original cist (gift). The dis- persed distribution of the rarities is circumstantial indication for this. Also, most of the lámina items (Fig. 10) do not match or conform to being parts of the same artefact (e.g. headdress, shirt). Many are irreg- ular, cut into expedient and unusual shapes, or bro- ken haphazardly into smaller fragments, then perfo- rated expediently. Formal heterogeneity (e.g. colour, shape), lack of standardization and pieces at differ- ent stages of production also characterize the beads. It is reasonable to suggest that the majority were from different sources, probably acquired opportunis- tically, and deposited as periodic votives. ${ }^{17}$ Spanish accounts observed that the capac hucha shrines saw continued veneration and remembrance long after the sacrifice (Hernández Príncipe 1923, 62-3; Mac- Cormack 2000, 113, 122; Zuidema 2015, 8-9). The Yayno case may be an archaeological instance of this practice.

In discussing the capac hucha cycle (Fig. 2), the ethnohistoric literature informs especially on steps A, B, $\mathrm{C}$ and $\mathrm{E}$. Archaeology, meanwhile, has focused almost exclusively on the behaviours that compose steps A and $\mathrm{B}$, particularly contexts at high mountain locations with child remains and miniature figurines. Although other interpretations cannot be ruled out, the data from Yayno accord well with a scenario that sees the Inka offering context arising due to a huaca's interaction with local groups (C), post-interment ven- eration (D) and reception of sumptuaries due to Inka patronage $(\mathrm{F})$.

Regardless of a specific capac hucha identification, the larger issue is to account for an Inka-style offering at Yayno. Not much systematic archaeology has been conducted on the Inka period in the Conchucos re- gion, but the region saw intensive state presence (Her- rera 2003; Ibarra 2009), including in the Pomabamba valley (Vidal Espinoza 2014). The Inka incorporated the Conchucos region (east of the Cordillera Blanca and west of the Río Marañon) and its ethnic groups, including Pincos, Piscobamba, Conchucos and Sihuas peoples. These were small lordships, made up of ranked ayllu groups and numbering up to several thousand people (Cook 1977; Druc 2009; León Gomez 2003).

Inka presence in the Conchucos is currently best known for a major prehispanic road which connects the provincial centre of Huánuco Pampa, on the southeastern margin of Ancash (Morris \& Thomp- son 1985), to important northern provinces (e.g. Ca- jamarca, Quito). Imperial installations, settlement re- occupations and subsidiary roads have been identi- fied (Astuhuamán G. \& Espinoza C. 2006; Bernabé 2009; Serrudo 2003; Vidal Espinoza 2014), but none is yet known for the immediate vicinity of Yayno. Var- ious modern towns (e.g. Piscobamba, Pomabamba, Conchucos) were built above Inka settlements. Classic Inka cut stone blocks are found in towns throughout the region, robbed from nearby sites and repurposed for new buildings and other uses (Apolín G. 2009, 38-40). 
Although in ruins, it seems likely that Yayno continued to be prominent in the local imaginary during Inka times. Today, the site lies at the crossroads of a half-dozen agro-pastoral villages around the flanks of the mountain. For generations, the footpaths which converge at Yayno have been traversed on a regular basis by the mountain's inhabitants, who see and ex- perience Yayno as the mediating centre (M. Jaramillo pers. comm., 2007). It is also the region's main archae- ological landmark and the focus of local cultural iden- tity, folklore and folkloric performances (Apolín G. 2009; Escudero Vega 2007). Yayno's unique geological and visual features, mentioned previously, continue to be prominent as ways to distinguish the mountain and navigate space. Notably, pilgrimages also ascend Yayno today to visit a natural rock formation wor- shipped annually as an image of the Virgen de Can- delaria, 'Mama Canchi' (Escudero Castillo 2007). Fi- nally, historical sources and ethnography in the re- gion relate that ancient hilltop ruins, more generally, are perceived as key physical embodiments of the mythic past, the feats of giants and ancestors (Ven- turoli 2011; Walter 2006). Inka political integration of the Pomabamba area, I contend, entailed physical and symbolic incorporation of the region's most promi- nent, sacred place.

Other high-altitude ridge-top sites throughout Ancash were reoccupied by the Inkas and may have been places for state-sanctioned offerings (Advincula

Z. \& Chirinos P. 2000; Herrera 2005; Lane 2011; 2018; Lau

2016, 165-77; Reichlen 1961). Like the Yayno cist, small

box-like compartments in these sites almost cer-tainly held

high-status human and object offerings: some were

hollowed out of living rock or boulders. The practices

were implicated in a 'cult of water', a concern also visualized in schematic representations of landscape at the sites themselves - carved directly onto bedrock and depicting mountains, canals, rivers and lakes/reservoirs.

Relict canals are located near these sites, which are consistent with the mediating role of sacred places

(Advincula Z. \& Chirinos P. 2000; Herrera 2005; Lane 2018). Managing territories, rights to land and water resources, and local abundance, it should be restated, were integral to the Inka logic for capac hucha (Hernández

Príncipe 1923; Zuidema 1973). The precious items are relevant in this respect because of their associations to fertility and cosmo- logical power. The Inka closely monitored the circula- tion of sumptuaries in

Tawantinsuyu, especially gold, silver, metal ore and Spondylus shell (e.g, D'Altroy 2002, 255, 298-303).

Their release to provinces was limited, and at times very conspicuously as 'gifts and offerings' for the huacas. For Andeans, Spondylus shell, or mullu, was among the most valuable of offerings: the preferred food of the gods and given to sup- plicate them for life-giving water and rain (Blower 2001). The nearest source was the warm waters off the Ecuadorian coast; the great quantities at Yayno demonstrate privileged participation in the empire's potent trade network. Gold had been used in earlier Recuay times, but was usually limited to cast objects with gilt surfaces. Spondylus shell and gold láminas have been found in capac hucha contexts elsewhere, but not in this quantity (Andrushko et al. 2011, 325). Both shell and metalwork were customary offerings to huaca shrines and mountains (Besom 2009, 100-

103) and in offering caches and burials (Farrington 2013). The large tupu, kero, ceramic forms and obsidian were also intrusive. Finally, the cist feature itself has no precedent at Yayno; no other burial or in situ hu- man skeletal material has been encountered through excavations.

The red-orange bivalve, Spondylus sp., is often linked to female fertility, the ocean and watery abundance (Blower 2001; Pillsbury 1996). The gold foil láminas, meanwhile, were probably linked to the male, solar brilliance of Inka divine power (Dransart 2000; Herring 2015). This was complemented by the two female shawl pins; silver was seen as the 'tears of the moon', won from ore and mined from the earth (often gendered female). The great bulk of the beads (turquoise- and green-coloured stone) emphasize the colours of water and verdant growth, and have tel- luric or mountain/underworld associations as mined materials. ${ }^{18}$

Besides the textile's brown-coloured fibres, the other discernible colour was the greenish-blue corro- sion of the metal pins and hammered copper beads. The oxidation (due to exposure to air, soil and water) also re-coloured different parts of the skull. It is not impossible that this post-depositional effect had sym- bolic resonance during the offering process and with the gift's transformation (Blower 2001, 215). In the An- des, of course, copper and silver are products of the earth; and ores are said to be like potatoes, which grow in and are harvested from mountains (Helms 2012, 107). That many of the precious items were unique, fragmented and unworked is consistent with early Spanish accounts observing that Inka offerings were gifted, at least in part, to assemble tokens of rare, pre- cious materials with pronounced colour, spatial and gender associations (Reinhard \& Ceruti 2010, 143). ${ }^{19}$

The emphasis on material complementarity was also reinforced by paired objects (e.g. copper-silver tupu) or objects with complementary roles, such as the pottery vessels. The urpu featured in the storage and serving of liquids, particularly chicha maize beer, while the pedestalled olla was used for cooking or 
reheating food, for relatively small personal por- tions (Bray 2003, 11-15). Both vessels, if full, probably required two persons to carry them. The other notable play or disparity with scale concerns the oversized tupu and the small child (for another example, see Besom 2013, 79). Future work may help to identify the sources of the child remains and accompanying items (e.g. lapidaries, obsidian, goldwork, camelids). The offering context did not reveal evidence of feathers, guinea pig, coca leaf or maize, the other common gifts for mountain huacas during Inka and colonial times (Besom 2013; Reinhard \& Ceruti 2010). Finally, no colonial materials were identified in the offering area, suggesting that colonial items were not part of the veneration activities, or that the activities did not continue long into colonial times.

Overall, the long-distance materials formed part of a series of innovative practices associated with an Inka period intervention at a local sacred place. The range of exogenous items reiterates the redistribu- tive character of capac hucha-like ritual events, which linked valuables, people and resources from different parts of the Inka realm (Duviols 1976). It is also con- sistent with the timing of a value system, when tra- ditional materials (Spondylus, hammered gold, rare- coloured materials, camelids) were still preferred, pre- cious and accessible in quantity to give back as return gifts to nourish Yayno.

\section{Conclusions}

The Yayno investigation helps characterize Inka state- craft in north-central Peru. In addition to heavy in- vestment in roads and buildings, Inka control of the Conchucos region opened up long-distance trade net- works and promoted special activities for their use. The Inka also co-opted a key ancient ruin, Yayno, to establish an offering akin to capac hucha known else- where. What is most remarkable is the quantity of rare items and the fundamentally special ritual character of the Inka presence. More research is needed, but the record thus far shows no evidence for other kinds of state intervention at Yayno, suggesting that it was the place (the mountaintop and monumental ruins) that inspired gift relations with local groups.

The cist context must have registered as a very small initiative in Tawantinsuyu's vast state project. But it has significant implications for considering its gift economy, not least in relation to Maussian insights introduced earlier (gift giving as social contract; a se- quence of exchange stages; the attachment and trans- formative potency of the 'total prestation' for the par- ticipants). The most visible production of persons is of the sacrificed individual, a child who underwent a series of corporeal and symbolic transformations. The body's elaborate treatment and alteration, historic texts tell us, precipitated apotheosis at the shrine lo- cation. Styled as Inka (vessels, kero, tupus), the offer- ing should be taken as an act of local allegiance to the Inka. While this publicly acknowledged subordinate subjects, it also recognized the agency of local groups in entering and obliging the Inka system. This was the highly bespoke impact of the Inka 'total presta- tion', the aesthetic precision of their provincial rela- tions which inspired their former subjects to recognize and feel indebted to their gift(s) many generations af- ter their demise.

Ultimately, the Yayno case contributes to the variability of offering contexts that have formal resemblances to capac hucha. To date, the record of this empire-wide system of reciprocity and redistribu- tion has focused on patterning on mountain glaciers; Yayno's context adds to the record of related offer- ings found at major archaeological ruins. The exist- ing record should hardly be seen as a complete sam- ple, however. Additional cases in the future will al- most certainly widen the spatial, diachronic and be- havioural variability of capac hucha-like ceremonial practices.

A crucial finding is that the Inka offering, once made, became a place itself for repeated visits and additional gifts/offerings. Abundant dedicatory items, their formal patterning and taphonomy indicate an enduring interest in the location after its christening. It has been argued that these offerings were made to the ancient ruin during periodic visits by local peo- ples who identified with the huaca/shrine. The offer- ing does not seem to have violated or appropriated the huaca, as much as it revitalized it or enhanced its prestige and status; subsequent offerings to it, found near the summit, countenanced the huaca as a whole, newly transformed by Inka sanction.

The offering at Yayno, and the gift economy, were not of routinely forgotten transactions, nor of objects liberated from personal connections. A capac hucha sacrifice could neither be a pure gift nor a mere com- modity, for it obliged recognition and future recipro- cation. Neither was the child stable in its identity dur- ing capac hucha ritual: its associations and sponsorship changed. What was important was a set of oscillating statuses, at once biographical and ontological (namely provincial Inka and object subject), in the passage of a child turning into a prestation, then sacrificial of- fering and finally enshrined ancestor/huaca. The sta- tuses accrued to the gift over time and coincided with the child's trajectory as a gift. In moving to and from the Other, it was the precisely the gift's protean qual- ity to be remade which ensured its desirability. The 
child-gift became, endowed and obliged wherever it went.

If the idolatries accounts offer insight into the impact of the Inka empire, what its former subjects stressed in their testimonies is sobering. Of all the empire's doings, it was the capac hucha that lasted in their memory - even nearly a century after the Inka collapse. The splendour and acts of capac hucha resonated much more than the solar cult, feasting, mass resettlement, road system or other monumental constructions - stuff more customarily understood as the key engines and signs of state power. Native An- deans, meanwhile, remembered Tawantinsuyu most for its highly mutable gifts, rather than for the other, more durable residues of conquest.

\section{Acknowledgements}

Thanks are owed to the comuneros of Huanchacbamba, Asuac and Putaca, who enabled the excavations, and The British Academy, Sainsbury Research Unit and Peru's Insti- tuto Nacional de Cultura (RDN 1220/INC, 25 Jul 2006), who supported the fieldwork and analysis. I am grateful to Silvia Milla, Italo Sauñe, Martha Bell, Steve Wegner, Nilton Luya, Katy Rodriguez, Alejandro Velasco, Gabriel Ramón, Mari- ano Jaramillo, Donato Apolín, Julio Escudero and others, who all aided fieldwork at Yayno. I am grateful to Emma Pomeroy and Mirko Brito, who analysed the human and textile remains, respectively, as well three peer reviewers; any errors of interpretation remain my own. This study is dedicated to R. Tom Zuidema (1927-2016), whose work on highland Ancash ancestor veneration and capac hucha con- tinues to inspire.

\section{Notes}

1. See recent debates in Hau (https://www.haujournal. org/index.php/hau/issue/archive), accessed 6 March 2018.

2. This examination expands and updates an earlier, syn- optic treatment of the Yayno context (Lau 2016).

3. Several Andean exceptions are Baitzel \& Goldstein (2014); Wilson et al. (2007).

4. There are archaeological cases of sacrifices up to 16 or more years of age (Reinhard \& Ceruti 2010, 104-6).

5. 'Cosmic polity'; essentially the system/world of hierarchical relations encompassing humans, supernatu- rals and non-human beings, with political significance (Sahlins 2012).

6. Ayllu describes corporate kin groups, whose members reckon descent from a common ancestor and share in ritual and work obligations.

7. The Quechua term minka refers to an 'asymmetrical reciprocal exchange', where the return good or service is not the same as was originally given (see Mayer 2002).
8. The outcrop was also used as a local quarry; it is un- clear, however, whether the outcrop was modified to gain its current visual appearance.

9. Resettlement to lower elevations may be associated with worsening climate during the Little Ice Age, from the thirteenth century (Lau 2011).

10. Most of the pit's diagnostic ceramic material was later Recuay in style, probably from the original floors and refuse deposits of the c20 compound, excavated to make the cist. Earlier materials may have also fallen in from above (another circular compound).

11. For a range of Inka offerings, including termination and burial patterns, see Besom (2013); Farrington (2013).

12. It resembles trapezoidal Spondylus necklace pendants at the Llullaillaco capac hucha site (Reinhard \& Ceruti 2010, 144).

13. Finds of raw blocks and broken/partly-worked lap- idary items (green-blue stone, shell) have been found at other multi-event offering sites, including near the ca-pac hucha context on La Plata Island (Dorsey 1901, 266) and in Cuzco and its vicinity (Farrington 2013, 172-6, 311, 322).

14. The known methods were by strangulation, exposure, head trauma and live burial. Such methods may have been to keep the body integral.

15. For child burials and offerings in Cuzco heartland, see Farrington (2013, 245-6, 278, 300, 322).

16. No metal figurines, those often associated with capac hucha, have yet been found (Besom 2013, ch. 7; Dransart 2000).

17. At Túcume, an Inka-period offering featured Spondylus shells and contained metal-foil miniature objects (e.g. headdresses, vessels, plants, animals) as well as irregu- lar pieces of cut sheet (Narváez 1995, 111-12).

18. The greenish-blue of turquoise and copper oxide has associations with death and ancestrality among mod- ern Andean communities. Blower (2001, 213-15) has noted the intentional combination of greenish-blue ma- terials (llacsa) with Spondylus shell in archaeological contexts.

19. An observation first made by Spanish chroniclers; see references in Reinhard \& Ceruti $(2010,143)$.

George F.Lau
Sainsbury Research Unit
UniversityofEastAnglia
Norwich NR4 7TJ
UK
Email: george.lau@uea.ac.uk

\section{References}

Advincula, Z. M., \& R. Chirinos, P., 2000. Reconocimien- tos del sitio arqueológico Caja Rumi, Cuenca Alta del Valle de Nepeña. Unay Runa 4, 23-9.
Andrushko, V.A., M.R. Buzon, A.M. Gibaja, G.F. McEwan,

A. Simonetti \& R.A. Creaser, 2011. Investigating a 
child sacrifice from the Inca heartland. Journal of Archaeological Science 38, 323-33.

Apolín G., D., 2009. Yayno: ciudad pre-Inka perdida en los An-des. Lima: Gráfica Industrial Alarcón.

Arriaga, P.J.d., 1999. La extirpación de la idolatría en el Piru (1621). Cuzco: Centro de Estudios Regionales 'Bartolomé de Las Casas'.

Astuhuamán G., C.W. \& D.A. Espinoza C., 2006. Una aproximación a la arqueología de Sihuas, Periodo Intermedio Temprano y Horizonte Tardío, in La complejidad social en la Sierra de Ancash, eds. A. Her- rera, C. Orsini \& K. Lane. Milan: Castello Sforzesco, 63-83.

Baitzel, S. \& P. Goldstein, 2014. More than the sum of its parts: dress and social identity in a provincial Ti- wanaku child burial. Journal of Anthropological Archae- ology 35, 51-62.

Bauer, B.S., 1998. The Sacred Landscape of the Inca: The Cusco Ceque system. Austin (TX): University of Texas Press.

Bernabé, J., 2009. Pukayacu: construcción de una puente col- gante con estructura de fibra en el sistema vial inca de Conchucos. Kullpi 4, 185-208.

Besom, T., 2009. Of Summits and Sacrifice: An ethnohistoric study of Inca religious practices. Austin (TX): University of Texas Press.

Besom, T., 2013. Inka Human Sacrifice and Mountain Worship.

Albuquerque (NM): University of New Mexico Press. Blower,

D., 2001. The many faces of mullu: more than just a Spondylus shell. Andean Past 6, 209-28.

Bortoluzzi, M. \& I. Martínez Armijo, 2011. La muerte es el mensaje: la doble comunicación de la capacocha inca entre don y sacrificio. Thule 30/31, 208-28.

Bray, T.L., 2003. Inka pottery as culinary equipment: food, feasting, and gender in imperial state design. Latin American Antiquity 14, 3-28.

Bray, T.L., 2009. An archaeological perspective on the An- dean concept of Camaquen: thinking through late PreColumbian ofrendas and huacas. Cambridge Archaeological Journal 19, 357-66.

Bray, T. (ed.), 2015. The Archaeology of Wak'as: Explorations of the sacred in the Pre-Columbian Andes. Boulder (CO): University of Colorado Press.

Bray, T.L., L. Minc, M.C. Ceruti, J.A. Chávez, R. Perea \& J. Reinhard, 2005. A compositional analysis of pottery vessels associated with the Inca ritual of capacocha. Journal ofAnthropologicalArchaeology 1,82-100.

Brito, M., n.d. Análisis de los textiles del contexto arqueológico inca del sitio arqueológico Yayno. Unpub- lished report.

Chapman, J., 2000. Fragmentation in Archaeology: People, places and broken objects in the prehistory of south eastern Europe. London: Routledge.

Cieza de León, P.d., 1985 [c. 1553]. Crónica del Peru. Segunda parte. Lima: Pontificia Universidad Católica del Peru. Clark,

J.G., 1965. Traffic in stone axe and adze blades. Economic History Review 18, 1-28.

Cook, N.D., 1977. La visita de los Conchucos por Cristóbal Ponce de León, 1543. Historia y Cultura 10, 23-45.
D'Altroy, T. \& T.K. Earle, 1985. Staple finance, wealth finance, and storage in the Inka political economy. Cur-rent Anthropology 26, 187-206.

D'Altroy, T.N., 2002. The Incas. Malden (MA): Blackwell. de

Bock, E. (ed.), 2010. Inca's Capac Hucha. Rotterdam: Wereldmuseum.

Dean, C., 2010. A Culture of Stone: Inka perspectives on rock. Durham (NC): Duke University Press.

DeMarrais, E., 2013. Art as an affecting presence: infant funerary urns in pre-Hispanic northwest Argentina. World Art 3, 101-19.

Dillehay, T.D. (ed.), 1995. Tombs for the Living: Andean mortu- ary practices. Washington (DC): Dumbarton Oaks.

Donnan, C.B., 2009. The Moche use of numbers and num- ber sets, in Andean Civilization: A tribute to Michael E. Moseley, eds. J. Marcus \& P.R. Williams. Los Angeles (CA): Cotsen Institute of Archaeology, 165- 80.

Dorsey, G., 1901. Archaeological Investigations on the Island of La Plata, Ecuador. (Publication 56, Anthropologi- cal Series Vol. II-5.) Chicago (IL): Field Columbian Museum.

Dransart, P., 2000. Clothed metal and the iconography of hu- man form among the Incas, in Precolumbian Gold: Tech- nology, style and iconography, ed. C. McEwan. London: British Museum Press, 76-91.

Druc, I.C., 2009. Tradiciones alfareras, identidad social y el concepto de etnias tardías en Conchucos, Ancash, Perú. Boletín del Instituto Francés de Estudios Andinos 38, 87106.

Duviols, P., 1967. Un inédit de Cristóbal de Albornoz: La instrucción para descubrir todas las guacas del Piru y sus camayos y haziendas. Journal de la Société des Américanistes 56, 7-39.

Duviols, P., 1976. La capacocha. Allpanchis 9, 11-57. Escudero

Castillo, J., 2007. Cerro sagrado: leyenda de Mama Canchi. Pomabamba 'Corazón de los Conchucos'1(2), 31.

Escudero Vega, F.(ed.), 2007. Revista Informativa de la Municipalidad de Huayllán. Huaraz: Imprenta 'Walo'.

Farrington, I.S., 2013. Cusco: Urbanism and archaeology in the Inka world. Gainesville (FL): University Press of Florida.

Fowler, C., 2004. The Archaeology of Personhood: An anthropological approach. London: Routledge.

Godelier, M., 1977. Perspectives in Marxist Anthropology. Cambridge: Cambridge University Press.

Goldstein, P.S., 2000. Exotic goods and everyday chiefs: longdistance exchange and indigenous sociopolitical development in the south central Andes. Latin Ameri- can Antiquity 11(4), 335-61.

González Holguin, D., 1989 [1608].Vocabulario de la lengua general de todo el Peru llamada lengua Qquichua o del Inca. Lima: UNMSM.

Graeber, D., 2001. Toward an Anthropological Theory of Value: The false coin of our own dreams. New York (NY): Pal- grave.

Gregory, C., 1982. Gifts and Commodities. New York (NY): Academic Press. 
Hastorf, C.A., 1993. Agriculture and the Onset of Political Inequality before the Inka. Cambridge: Cambridge University Press.

Helms, M.W., 1993. Craft and the Kingly Ideal. Austin (TX): University of Texas Press.

Helms, M.W., 2012. Nourishing a structured world with liv- ing metals in Bronze Age Europe. World Art 2, 105-18.

Hernández Príncipe, R., 1923. Mitología andina - idolatrías en Recuay. Inca 1, 25-78.

Herrera, A., 2003. La Serpiente de Oro y los Inkas: la ocupación Inka en el Alto Marañón y el puerto balsero de Pogtán. Boletín de Arqueología PUCP 7, 189-215.

Herrera, A., 2005. Territory and Identity in the Pre- Columbian Andes of Northern Peru. PhD disserta- tion, University of Cambridge.

Herring, A., 2015. Art and Vision in the Inca Empire: Andeans and Europeans at Cajamarca. New York (NY): Cam- bridge University Press.

Hirth, K. \& J. Pillsbury (eds.), 2013. Merchants, Markets, and Exchange in the Pre-Columbian World. Washington (DC): Dumbarton Oaks.

Ibarra, B. (ed.), 2009. Historia prehispánica de Huari: 3000 años de historia desde Chavín hasta los Inkas. Huari: Instituto de Estudios Huarinos.

Johnson, A.W. \& T. Earle, 1987. The Evolution of Human Societies: From foraging group to agrarian state. Palo Alto (CA): Stanford University Press.

Klaus, H.D. \& J.M. Toyne (eds.), 2016. Ritual Violence in the Ancient Andes. Austin (TX): University of Texas Press. Kosiba, S.,

2015. Ofblood and soil: tombs, w'akas and the nat- uralization of social difference in the Inka heartland, in The Archaeology of W'akas, ed. T. Bray. Boulder (CO): University of Colorado Press, 167-212.

Lane, K.J., 2011. Hincapié en los Andes nor-centrales: la presencia inca en la Cordillera Negra, sierra de Ancash, in Arquitectura prehispánica tardía: construc-ción y poder en los Andes centrales, eds. K. Lane \&

M. Luján Davila. Lima: Universidad Católica Sedes Sapentiae.

Lane, K.J., 2018. Over rock and under stone: carved rocks and subterranean burials at Kipia, Ancash, AD 1000- 1532. Open Archaeology 4, 299-321.

Lau, G.F., 2010. House forms and Recuay culture: residential compounds at Yayno (Ancash, Peru), a fortified hill- top town, AD 400-800. Journal of Anthropological Archaeology 29, 327-51.

Lau, G.F., 2011. Andean Expressions: Art and archaeology of the Recuay Culture. Iowa City (IA): University of Iowa Press.

Lau, G.F., 2013. Ancient Alterity in the Andes: A recognition of others. London: Routledge.

Lau, G.F., 2016. An Archaeology of Ancash: Stones, ruins and communities in ancient Peru. London/Abingdon: Routledge.

Lazzari, M., 2005. The texture of things: objects, peo- ple and social spaces in Northwest Argentina (first millennium AD), in Archaeologies of Materiality, ed.

L. Meskell. Oxford: Wiley-Blackwell, 126-61.
León Gomez, M.A., 2003. Espacio geográfico y organización social de los grupos étnicos del Callejon de Conchu- cos durante los siglos XVI y XVII, in Arqueología de la sierra de Ancash: propuestas y perspectivas, ed. B. Ibarra

A. Lima: Instituto Runa, 457-66.

Lévi-Strauss, C., 1969. The Elementary Structures of Kinship. Boston (MA): Beacon Press.

MacCormack, S., 1991. Religion in the Andes: Vision and Imagination in Early Colonial Peru. Princeton (NJ): Princeton University Press.

MacCormack, S., 2000. Processions for the Inca: Andean and Christian ideas of human sacrifice, communion and embodiment in Early Colonial Peru. Archiv fur Religionsgeschichte 2, 110-40.

Mathews, J.P. \& T.H. Guderjan (eds.), 2017. The Value of Things: Prehistoric to contemporary commodities in the Maya region. Tucson (AZ): University of Arizona Press.

Mauss, M., 1967 [1925].The Gift: Forms and Functions of Exchange in Archaic Societies. New York (NY): Norton.

Mayer, E., 2002. The Articulated Peasant: Household economies in the Andes. Boulder (CO): Westview Press.

McEwan, C. \& M. van de Guchte, 1992. Ancestral time and sacred space in Inca state ritual, in Ancient Americas: Art from sacred landscapes, ed. R.F. Townsend. Chicago (IL): Art Institute of Chicago, 358-71.

Meddens, F., K. Willis, C. McEwan \& N. Branch (eds.), 2014. Inca Sacred Space: Landscape, site and symbol in the An-des. London: Archetype.

Morris, C. \& D.E. Thompson, 1985. Huánuco Pampa: An Inca city and its hinterland. London: Thames \& Hudson.

Morris, I., 1986. Gift and commodity in Archaic Greece. Man (n.s.) 21, 1-17.

Munn, N.D., 1986. The Fame of Gawa: A symbolic study of value transformation in a Massim (Papua New Guinea) society. Cambridge: Cambridge University Press.

Murra, J.V., 1980. The Economic Organization of the Inka State. (Research in Economic Anthropology, Supplement 1.) Greenwich (CT): JAI Press.

Narváez, A., 1995. The pyramids of Túcume: the monumen- tal sector, in Pyramids of Túcume: The quest for Peru's forgotten city, eds. T. Heyerdahl, D. Sandweiss \& A. Narváez. London: Thames \& Hudson, 79-130.

Nielsen, A., 2007. Bajo el hechizo de los emblemas: políticas corporativas y tráfico interregional en los Andes Circumpuneños, in Producción y circulación prehispánicas de bienes en el surandino, eds. A. Nielsen, M.C. Rivolta, V. Seldes, M.M. Vázquez \& P. Mercolli. Córdoba: Edi- torial Brujas, 393-412.

Oliver, J.R., 2009. Caciques and Cemí Idols: The web spun by Taíno rulers between Hispaniola and Puerto Rico. Tuscaloosa (AL): University of Alabama Press.

Papadopoulos, J. \& G. Urton (eds.), 2012. The Construction of Value in the Ancient World. Los Angeles (CA): Cotsen Institute of Archaeology.

Pillsbury, J., 1996. Thorny oyster and the origins of empire: implications of recently uncovered Spondylus imagery 
from Chan Chan, Peru. Latin American Antiquity 7(4), 31340.

Pomeroy, E., n.d. Osteological analysis of partial child cra- nium from Sector 3, Operation 16, Locus 9 (Yayno). Unpublished report.

Reichlen, H., 1961. À propos des découvertes d'urnes en pierre dans les Andes de Pomabamba (Ancash). Travaux de L'Institut Français d'Études Andines 8, 111-17.

Reinhard, J. \& M.C. Ceruti, 2010. Inca Rituals and Sacred Mountains: A study of the world's highest archaeological sites. Los Angeles (CA): Cotsen Institute of Archaeol- ogy Press.

Rostworowski, M., 1999. History of the Inca Realm. Cambridge: Cambridge University Press.

Rowe, J.H., 1946. Inca culture at the time of the Spanish conquest, in Handbook of South American Indians, Vol- ume 2: The Andean civilizations, ed. J. Steward. (Bulletin 143.) Washington (DC): Bureau of American Ethnol- ogy, 183330 .

Sahlins, M., 1972. Stone Age Economics. New York (NY): Aldine Publishing.

Sahlins, M., 2012. Alterity and autochthony: Austrone- sian cosmographies of the marvelous. Hau: Journal of Ethnographic Theory 2, 131-60.

Salomon, F., 2004. Andean opulence: indigenous ideas about wealth in Colonial Peru, in The Colonial An- des: Tapestries and silverwork, 1530-1830, eds. E. Phipps, J. Hecht \& C. Esteras Martín. New York (NY): Metropolitan Museum of Art, 114-24.

Salomon, F. \& G. Urioste (eds.), 1991. The Huarochirí Manuscript: A testament of ancient and colonial religion. Austin (TX): University of Texas Press.

Schroedl, A., 2008. La Capacocha como ritual político. Bul- letin del'Institutfrançaisd'études andines 37, 19-27.

Serrudo, E., 2003. Sistema vial y asentamientos Inca en la provincia de Huari, in Arqueología de la sierra de Ancash: propuestas y perspectivas, ed. B. Ibarra. Lima: Instituto Cultural Runa, 429-43.

Sillar, B., 2012. Patrimoine vivant: les illas et conopas des foy- ers andins. Techniques \& Culture 58, 66-81.

Strathern, M., 1988. Gender of the Gift: Problems with women and problems with society in Melanesia. Berkeley (CA): University of California Press.

Thomas, N., 1991. Entangled Objects: Exchange, material cul-ture, and colonialism in the Pacific. Cambridge (MA): Harvard University Press.

Urton, G., 1997. The Social Life of Numbers: A Quechua ontol- ogy of numbers and philosophy of arithmetic. Austin (TX): University of Texas Press.

Venturoli, S., 2011. Los hijos de Huari: etnografía y etnohistoria de tres pueblos de la sierra de Ancash, Peru. Lima: Fondo Editorial, Pontificia Universidad Católica del Peru.

Vetter,L.\& P.Carcedo, 2009. El tupu: símbolo ancestral de iden- tidad femenina. Lima: Gráfica Biblos.
Vidal Espinoza, E., 2014. Filiación cultural y patrones de asentamiento de los sitios arqueológicos ubicados en la margen izquerda del valle alto del Río Pomabamba. Licentiate thesis, Universidad Nacional Santiago Antúnez de Mayolo, Huaraz.

Walter, D., 2006. Los sitios arqueológicos en el imaginario de los campesinos de la Cordillera Blanca (Sierra de Ancash), in Complejidad social en la arqueología y antropología de la sierra de Ancash, Peru, eds. A. Her- rera, C. Orsini \& K. Lane. Milan: Comune di Milano- Raccolte Extra Europee del Castello Sforzesco, 177-90.

Weiner, A.B., 1992. Inalienable Possessions: The paradox of keeping-while-giving. Berkeley (CA): University of California Press.

Wilson, A., E. Brown, C. Villa, et al., 2013. Archaeological, radiological, and biological evidence offer insight into Inca child sacrifice. Proceedings of the National Academy of Sciences 110, 13322-7.

Wilson, A., T. Taylor, M.C. Ceruti, J.A. Chávez, J. Reinhard, V. Grimes \& W. Meier-Augenstein, 2007. Stable iso- tope and DNA evidence for ritual sequences in Inca child sacrifice. Proceedings of the National Academy of Sciences 104, 16456-61.

Yauri Montero, M.E., 2000. Leyendas ancashinas. Lima: Taller Gráfico Lerma Gómez.

Zuidema, R.T., 1973. Kinship and ancestor cult in three Peru- vian communities: Hernández Príncipe's account of 1622. Bulletin de l'Institut français d'études andines 2(1), 16-33.

Zuidema, R.T., 1982. Bureaucracy and systematic knowl- edge in Andean civilization, in Inca and Aztec States, 1400 1800, eds. G.A. Collier, R.I. Rosaldo \& J.D. Wirth. New York (NY): Academic Press, 419-58.

Zuidema, R.T., 2015. The ushnus of Cuzco and sacred centres in Andean ethnography, ethnohistory and archaeol- ogy, in Inca Sacred Space, eds. F. Meddens, K. Willis,

C. McEwan \& N. Branch. London: Archetype, 5-28.

\section{Author biography}

George F. Lau is Reader at the Sainsbury Research Unit for the Arts of Africa, Oceania \& the Americas (University of East Anglia, Norwich). He specializes in the arts and ar- chaeology of the ancient Americas. His writings highlight Central Andean developments, especially material culture, complexity, ritual practices and diachronic change. Among his publications are the books: Ancient Community and Econ- omy at Chinchawas (Yale University Press, 2010); Andean Ex- pressions: Art \& archaeology of the Recuay Culture (University of Iowa Press, 2011); Ancient Alterity in the Andes: A recogni- tion of others (Routledge, 2013) and An Archaeology of Ancash (Routledge, 2016). He is also editor of the journal World Art. 